\title{
Detailed descriptions of the lower-middle Triassic and Permian formations using cores and gamma-rays from the EPS- 1 exploration geothermal borehole (Soultz-sous-Forêts, Upper Rhine Graben, France)
}

\author{
C. Aichholzer ${ }^{1 *}\left(\mathbb{B}\right.$, Ph. Duringer ${ }^{1}$ and A. Genter ${ }^{2}$
}

\section{*Correspondence:}

caichholzer@unistra.fr

${ }^{1}$ Ecole et Observatoire des

Sciences de la Terre (EOST),

Institut de Physique du Globe de Strasbourg (IPGS), CNRS/

Unistra UMR 7516, Université de Strasbourg (Unistra), 1 rue Blessig, 67084 Strasbourg Cedex, France

Full list of author information is available at the end of the article

\begin{abstract}
In the 1950s, a petroleum well in Soultz-sous-Forêts (no 4589; Upper Rhine Graben, France) reached the Lettenkohle (Triassic) at $830 \mathrm{~m}$ depth. During the exploration phase at Soultz-sous-Forêts, the first enhanced geothermal system pilot project in the world, the well was core-deepened up to $2227 \mathrm{~m}$ into the granitic basement (then renamed EPS-1). The objectives of this deeper well were (i) to explore the granitic fractured reservoir and (ii) provide a precise geological characterization of the Soultz-sousForêts horst. This paper presents the first complete core analysis of the sedimentary formations observed in the EPS-1 cores (from the middle Muschelkalk to the Permian) in conjunction with the gamma-ray log description and field works. The detailed descriptions of the geological formations encountered in the well are presented with photo boards displaying the most characteristic facies of each formation, since the wells are rarely cored, especially in the Muschelkalk. This study also aims to describe the gamma-ray log to provide a strong baseline for future geothermal well exploration in this area (or old well reinterpretations). At this time, it is the only available reference for the complete section: Muschelkalk to Permian sedimentary formations.
\end{abstract}

Keywords: Upper Rhine Graben, Core, Gamma-ray, Stratigraphy, Permian, Buntsandstein, Muschelkalk

\section{Introduction}

The Upper Rhine Graben (URG), located in eastern France, is an attractive region for the development of new renewable energy projects, such as deep geothermal energy. Over the last few decades, many projects have taken place in the French part of the URG, including electricity production and/or industrial heating at Soultz-sous-Forêts, Rittershoffen, Illkirch-Graffenstaden and Vendenheim (the latter two being underway). The first Enhanced Geothermal System (EGS) pilot project in the world, located in Soultzsous-Forêts (northwest URG), was drilled in the 1990s. Between 1990 and 1991, for detailed geothermal exploration research, an abandoned petroleum well (called no 4589; reaching the Lettenkohle, $830 \mathrm{~m}$ deep) was core-deepened from 930 to $2227 \mathrm{~m}$ (the first

(c) The Author(s) 2019. This article is distributed under the terms of the Creative Commons Attribution 4.0 International License (http://creativecommons.org/licenses/by/4.0/), which permits unrestricted use, distribution, and reproduction in any medium, provided you give appropriate credit to the original author(s) and the source, provide a link to the Creative Commons license, and indicate if changes were made. 
$100 \mathrm{~m}$ corresponding to the interval $830-930 \mathrm{~m}$ was drilled in rotary mode; the well was renamed EPS-1 after this operation). The main objective of the EPS- 1 well was to reach the granitic basement to perform hydraulic tests of possible future geothermal wells of the Soultz-sous-Forêts project. Regarding geothermal energy, these are almost the only continuous cores available for the deepest part of the URG sedimentary cover (Genter and Traineau 1996). Based on a very good core recovery of close to $99 \%$, Perrin and Baudu (1992) worked on the EPS-1 cores to provide a depth recalibration. Combining the correlations between the gamma density measurements of the cores with the gamma-gamma log from the well, they gave a fine scale-resolution depth recalibration, observing the nonoverlapping areas of the successive passes and missing material between the nested cores.

The cores have provided numerous pieces of valuable information about the middle Muschelkalk (Anisian) up to the Paleozoic Variscan granitic basement, including the Permian sedimentary formations. If the geological results from the granite cores analysis are already described by Genter and Traineau (1992), there is still no precise description of the sedimentary part whereas these cores are very useful especially for the identification of the formations. For the middle and lower Muschelkalk, there are only a small number of outcrops which are in addition of poor qualities most of the time. With no quarries and excessively rare outcrops, having these cores from the middle Muschelkalk up to the basement represents the only available, continuous and complete reference of this sedimentary interval. Extensive formations over the continent, the Muschelkalk and the Buntsandstein formations, are relatively similar in facies and thickness throughout the URG; therefore, these cores are of great interest for any future geothermal project in the graben.

In this geological approach, we logged the lower part of the middle Muschelkalk, the entire lower Muschelkalk, the complete Buntsandstein formation (Triassic and Permian) of the URG. The second objective of this work was to characterize the gammaray (GR) signal corresponding to this sedimentary succession to provide a reference for future geothermal projects planned in this area. Indeed, during the drilling operation, the limited knowledge of the sedimentary formations presented challenges for setting the casing and managing the borehole strategy (trajectometry, technical design). Therefore, having a GR signature for each sedimentary formation could be a powerful tool for close to real-time recognition of the geological boundaries, taking into account that most of the geothermal wells are drilled in rotary mode (cuttings) and, thus, no cores are available due to cost issues. The GR signature is also a great tool for the reinterpretation of old well data of which the sedimentary cover was not always the subject of a specific analysis. For example, the GR signature collected during the recent drilling of GRT-1 (Géothermie Rittershoffen 1; Fig. 1. Duringer et al. 2019) was a great help for the Soultz-sous-Forêts GPK wells reinterpretation (Aichholzer et al. 2016). Thus, to be sure of the given lithostratigraphic limits, an assessment of the geological formations was conducted through the comparison of ESP-1 core analyses and field data on available outcrops. Afterwards, the stratigraphic log was put in superimposed on to the GR data to observe if there was a particular signature for each formation. In this paper, we present the cores and gamma-ray analyses from the middle and lower Triassic and Permian based on the EPS-1 core analysis. 


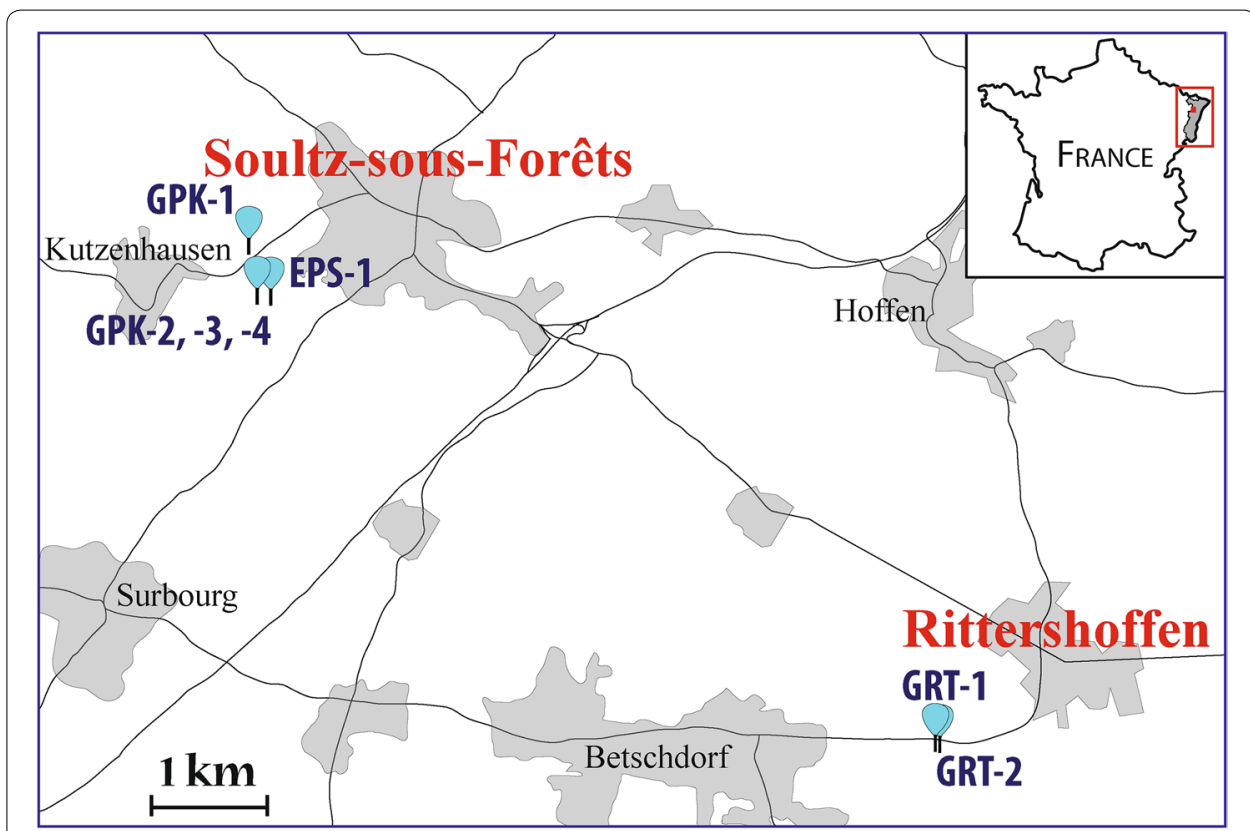

Fig. 1 Location of wellheads of EPS-1 exploration well, the GPK-1, GPK-2, GPK-3 and GPK-4 geothermal wells at Soultz-sous-Forêts and GRT-1 and GRT-2 at Rittershoffen. It is located in the French north-western part of the Upper Rhine Graben

\section{Context of the study}

The Upper Rhine Graben belongs to a series of faults of the West European Paleogene Rift System, which stretches for more than $1000 \mathrm{~km}$ from Spain to north of the Netherlands and finally to the North Sea (Illies 1967; Villemin and Bergerat 1987; Ziegler 1992; Schumacher 2002; Ziegler and Dèzes 2005; Rotstein et al. 2005; Berger et al. 2005b; Edel et al. 2007; Bauer et al. 2015). Located in northeastern France and southwestern Germany, the URG is one of the major tectonic structures of Western Europe, with a mean orientation NNE-SSW (N20 E; Bergerat 1987). As a rift, the URG is delineated by a system of major fault zones separating the sediment-filled graben (Tertiary history) from the uplifted graben shoulders on both the eastern and western sides (Paleozoic massif: Black Forest and Vosges, respectively). During the Cenozoic, by convergence between the African and European plates, the Alpine orogeny becomes a transtensional shear zone with an SSO-NNE orientation, the West European Rift System (Bourgeois et al. 2007). In the Middle Eocene (Lutetian) to the base of the Oligocene the first important rifts are set up in subsidence, as the URG, the Bresse Basin, the Saône and the Limagne graben. With the Alpine orogeny, the graben was established in the Tertiary, and the first synrift deposits are dated from the middle Eocene (Sittler 1965, 1992; Duringer 1988; Schuler 1988; Blanc-Valleron 1990; Sissingh 1998, 2003; Berger et al. 2005a, b). The URG is an asymmetric graben with much thicker deposits in the north than in the south (Sittler 1965, 1969a, b; Doebl and Olbrecht 1974; Sissingh 1998; Schumacher 2002; Rousse 2006; Hinsken et al. 2011). During the Chattian age, the subsidence, which had previously occurred in the southern part of the rift, moved gradually toward the north, producing very large deposits north of the graben, while the subsidence in the south remained consistently stable (Sittler 1965). The complete sedimentary cover from the basement top to the Quaternary of the Rhenish Graben consists of 
two major units: the Permian and Mesozoic prerift sedimentary formations and the synrift to postrift (Cenozoic and Quaternary) formations. In this work, we focus on the deepest part of the sedimentary cover: the lower part of the middle Triassic, the lower Triassic and the entire Permian units.

The Upper Rhine Graben has long been a basin of great economic interest for potash and petroleum exploration. Due to the latter, thousands of wells and seismic lines were undertaken in the region. In the 1930s, Haas and Hoffmann (1929) found a relationship between the thermal anomalies and oil accumulations in the Pechelbronn basin and analyzed more than 500 thermometer measurements at a deep of $400 \mathrm{~m}$ in old oil mines. They showed that an intense geothermal anomaly following the overall structure is located in the area of Soultz-sous-Forêts. This is why the European deep geothermal project took place at Soultz-sous-Forêts: by taking advantage of that abnormally high geothermal gradient (with temperature of $141^{\circ} \mathrm{C}$ at $2000 \mathrm{~m}$ depth) in the deep-seated fractured rocks to produce electricity (Gérard and Kappelmeyer 1987; Kappelmeyer et al. 1992). During that prosperous economic period of the early twentieth century, an old petroleum well (no 4589) was drilled at Soultz-sous-Forêts. This borehole was core-deepened in the 1990s for the Soultz-sousForêts geothermal project from $830 \mathrm{~m}$ to $2227 \mathrm{~m}$ depth (renamed EPS-1).

Five deep wells were drilled for the Soultz-sous-Forêts project (Fig. 1): EPS-1 (Exploration Puits Soultz 1) and four GPK (Géothermie Puits Kutzenhausen) wells, including GPK-1 (3600 m deep), between Soultz-sous-Forêts and Kutzenhausen (location on Fig. 1), and GPK-2, GPK-3 and GPK-4 (at 5090 m, $5000 \mathrm{~m}$ and $4985 \mathrm{~m}$ depth, respectively) drilled in the SSE, $400 \mathrm{~m}$ from GPK-1, between Soultz-sous-Forêts and Surbourg (location on Fig. 1). EPS-1 is a nearly vertical borehole in the sediments, while the GPK wells are vertical boreholes in the sedimentary part only. Few investigations have been done in the sedimentary part of EPS-1. Vernoux et al. (1995) did petrophysical and geological studies of the Buntsandstein cores whereas Bourquin et al. (2006) used EPS-1 GR log for a Buntsandstein basin scale correlation. Deep in the granitic basement, each well deviates away from each other to create a sufficiently horizontal space between the bottom of each well to avoid thermal losses between the injection and production zones. The magmatic basement intersected by the deep drillings is composed of two granites: a porphyritic monzogranite dated at 334.0+3.8/3.5 Ma and a two-mica granite dated at 327 $\pm 7 \mathrm{Ma}$ (Köhler 1989; Alexandrov et al. 2001; Stussi et al. 2002; Cocherie et al. 2004). These granites are affected by natural fractures related to the late Variscan history (reactivated during the Mesozoic and Cenozoic URG tectonic; Valley 2007; Dezayes and Lerouge 2019). Moreover, the upper part of this basement was affected by paleosupergene weathering before the deposits of the Permo-Triassic series (Genter and Traineau 1996; Hooijkaas et al. 2006). The position of Soultz-sousForêts wells on a horst structure enables reaching the top of the granite at a relatively high position ( 1400 m depth), limiting drilling time and costs.

\section{Materials and methods}

The old petroleum well (No 4589) in Soultz-sous-Forêts reached the Lettenkohle (Triassic, Upper Ladinian) at $830 \mathrm{~m}$ depth. Deepened from 830 to $930 \mathrm{~m}$ in rotary mode, no cores are available. From 930 to $2227 \mathrm{~m}$, it has been core-deepened for the geothermal exploration at Soultz (renamed EPS-1; Table 1). 
Table 1 Information about the EPS-1 exploration well, focusing on the MuschelkalkBuntsandstein section (interest of the study)

\begin{tabular}{|c|c|c|c|}
\hline \multicolumn{4}{|c|}{ TECHNICAL INFORMATION: EPS-1 well } \\
\hline Company & Socomine & Date deepening & 1990-1991 \\
\hline Field area & Soultz-sous-Forêts & Mud data & $\begin{array}{l}\text { Density } 1.10 \mathrm{~kg} / \mathrm{cm}^{3} \text {; composition: clay, } \\
\text { salt, calcium carbonate, viscosifiers }\end{array}$ \\
\hline Well coordinates & $\begin{array}{c}X: 1104.89 \text { and } Y: 1151.62 \\
\text { Z: } 174.9 \text { above MSL }\end{array}$ & Drilling equipment & $\begin{array}{c}\text { IDECO H1000 } \\
\text { Hook load } 156 \text { tonnes }\end{array}$ \\
\hline Initial depth & $933 \mathrm{~m}$ & Casing of the section & $4^{1 / 2 "}$ system (SK80 rods) \\
\hline Final depth & $2227.2 \mathrm{~m}$ & Bit size of the section & $4^{7 / 8^{\prime \prime}}(124 \mathrm{~mm})$ \\
\hline Deviation & $\begin{array}{l}\text { No deviation between } \\
0 \text { and } 1400 \mathrm{~m}\end{array}$ & Section data logged & $\begin{array}{c}\text { Gamma-ray: Muschelkalk to Permian } \\
\text { Sonic: Buntsanstein to Permian (poor quality) } \\
\text { BHTV acoustic log: Buntsandstein to Permian } \\
\text { Gamma-density on cores: Buntsandstein to Permian }\end{array}$ \\
\hline
\end{tabular}

This table gives the main technical information about the well and the logging operations. More details are given in the Final Report of EPS-1 (Degouy et al. 1992)

MSL mean sea level

From 930 to 1997 meters depth, the cores have a diameter of $78 \mathrm{~mm}$, and from there to $2227 \mathrm{~m}$, the diameter is $57 \mathrm{~mm}$ (Genter and Traineau 1991). The core recovery was excellent, close to $99 \%$. Core quality was also excellent except at the beginning of the coring operations between 930 and 940 m deep in the Middle Muschelkalk. The cores described here are all $78 \mathrm{~mm}$ in diameter. The cores are stored in boxes of $1 \mathrm{~m}$. Perrin and Baudu (1992) showed the nonoverlapping of the successive core passes and the lack of material between the nested cores with their depth recalibration. Thus, core depth and well data are fully depth matched with very good accuracy. As shown in those documents, the first meters were difficult to drill. The target was to drill 9-m-long cores. Due to technical drilling difficulties, the first meters of the cores are shorter in length and some portions of the cores are missing at approximately $935 \mathrm{~m}$ deep. Below $940 \mathrm{~m}$, the drilling operations proceeded as expected.

Time was spent in the Pechelbronn core shelter to precisely analyze the 484 meters of the cores from the lower part of the middle Muschelkalk to the base of the Permian formations. Time was also spent on the outcrops to observe most of the formations and to obtain representative samples for comparison with the cores, especially in the lower Muschelkalk, for which data are relatively scarce. The detailed log has been redrawn to show the main lithofacies and sedimentary features of each formation. Particular attention was also focused during this synthesis on the position of the main facies. Wireline logs were run in the EPS-1 borehole to measure the gamma-ray (GR), which registered the natural radioactivity in geological formations, as reported in gAPI. Thus, the GR signal was placed with regard to the geological log.

In this paper, the names of the formations are given in French, as defined by the last geological mapping of the region which uses the classical stratigraphic international scheme and the German nomenclature commonly accepted and used in the region for the name of the formation (Ménillet et al. 2015). The gamma-ray log has been logged in the vertical well; therefore, the depth of the cores and the depth of the GR can be easily 
compared. For the labeling of the figure, it is done in this paper as follows: (Figure Number, Box number in italic). In the following section, the core descriptions will be compared to the outcrop data to upstream the analyses.

\section{Results and discussion: top to bottom cores descriptions in relation with the gamma-ray log \\ Muschelkalk}

Top of Box 1 to the middle of Box 76, corresponding to depths of $933 \mathrm{~m}$ to $1001 \mathrm{~m}$.

The Muschelkalk formations (Schumacher 1890, 1891; Théobald 1952; Perriaux 1961; Haguenauer 1963; Schwarz 1970; Kozur 1974; Geisler 1978; Aigner 1979, 1985; Adloff et al. 1982; Duringer 1982, 1984, 1985; Geisler-Cussey 1986; Duringer and Vecsei 1998; Vecsei and Duringer 2003) represent the main marine episode within the Germanic Triassic and displays mainly argillaceous limestones, marl/limestone alternations, limestones, dolomites and dolomitic marls. Some anhydrite intervals in the lower part of the middle Muschelkalk also occur. If the upper Muschelkalk (Anisian-Ladinian) is a pure marine deposit, the middle Muschelkalk (Anisian) is shown to be the result of both evaporitic and shallow marine environments. The lower Muschelkalk (Anisian) represents the first marine transgression covering the siliciclastic fluvial-dominated Buntsandstein.

\section{Marnes Bariolées}

Top of Box 1 to the middle of Box 29, corresponding to depths of $933 \mathrm{~m}$ to $965 \mathrm{~m}$.

\section{Core observations}

The characterization of the upper contact is always difficult because the facies from the base of the previous formation (Dolomie à Lingules) is quite similar to the facies on the top of the Marnes Bariolées composed of a mal/dolomite alternation (Fig. 2). The main difference with the Dolomie à Lingules is the number of marls between the dolomite banks (thickness and frequency of marls increase progressively downward in the Marnes Bariolées at the expense of development of dolomite). In the EPS-1, the first 32 meters cored correspond to the Marnes Bariolées. The first nine meters of the cored well consists of dolomite and are strongly similar to the facies of the Dolomie à Lingules, but the usual alternation with dolomitic marls (Fig. 3B6) shows that the dolomite belongs to the top of the Marnes Bariolées. Immediately downwards, marly dolomite soon appear with great amount of anhydrite (Fig. 3B12). From boxes 13 to 19, the formation (Fig. 3B19 and B21) is strongly folded and fractured (Fig. 3B14 and B18). Close to the base, in Box 26, there exist one-meter-thick hydraulic fracture breccias, based on the observation of mineralized fractures and the total lack of typical sedimentary structures (Fig. 3B21 and B29).

Gamma-ray observations

From the massive dolomite of the Dolomie à Lingules, just above, the top of the Marnes Bariolées is marked by an increase in radioactivity attributed to the enrichment in marls (Fig. 4). Downwards, a great amount of anhydrite gives several strong low value pulses characterizing the middle part of the Marnes Bariolées. The anhydrite disappears toward 


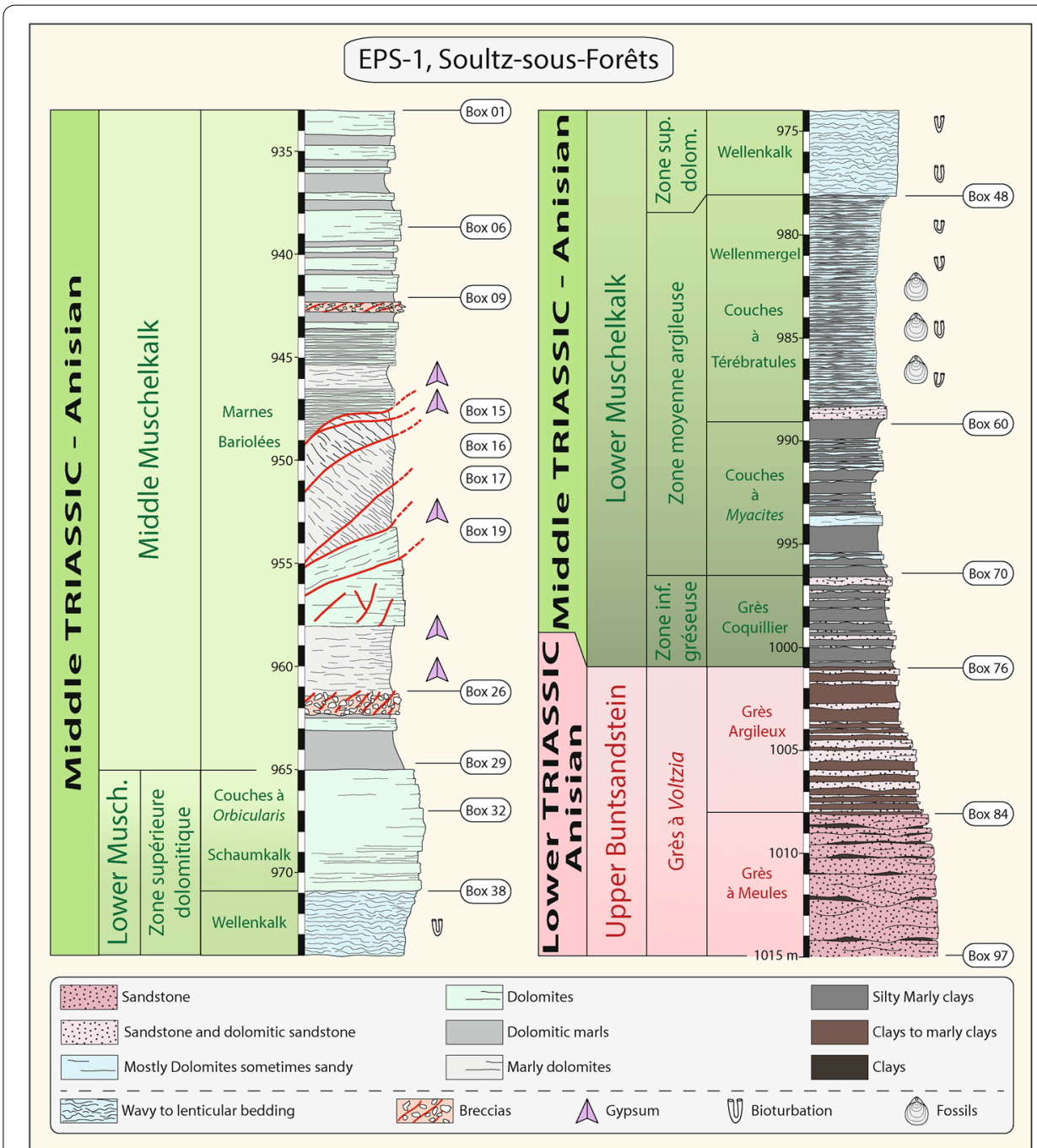

Fig. 2 Litho-chronostratigraphic log from the middle Muschelkalk (Anisian) to the upper Buntsandstein (Anisian), issued from the EPS-1 core analysis. This log presents from top to base the Marnes Bariolées, the Couches à Myophoria Orbicularis, the Schaumkalk, the Wellenkalk, the Wellenmergel, the Couches à Térébratules, the Couches à Myacites, the Grès Coquillier and the Grès à Voltzia facies observed on the cores. At the right of the log column, the occurence of gypsum, fossils and bioturbations is indicated. The cores are stored in boxes of 1-m-length; in the figure their labels are indicated. The number 01 corresponds to the top of the coring (middle Muschelkalk), as the number 542 the transition between the Permian and the granitic Variscan basement (not represented on this log which shows only the cores from top of the deepening)

the base and is replaced by marls that once again shifts the GR signal to the high values. The alternation between the clays, the dolomitic limestone banks and the marly dolomites explains the high frequency and amplitude of the GR signal throughout the rest of the formation.

\section{Couches à Orbicularis and Schaumkalk (or Schaumdolomit)}

From the middle of Box 29 to the base of Box 38, corresponding to depths of $965 \mathrm{~m}$ to $971 \mathrm{~m}$. 


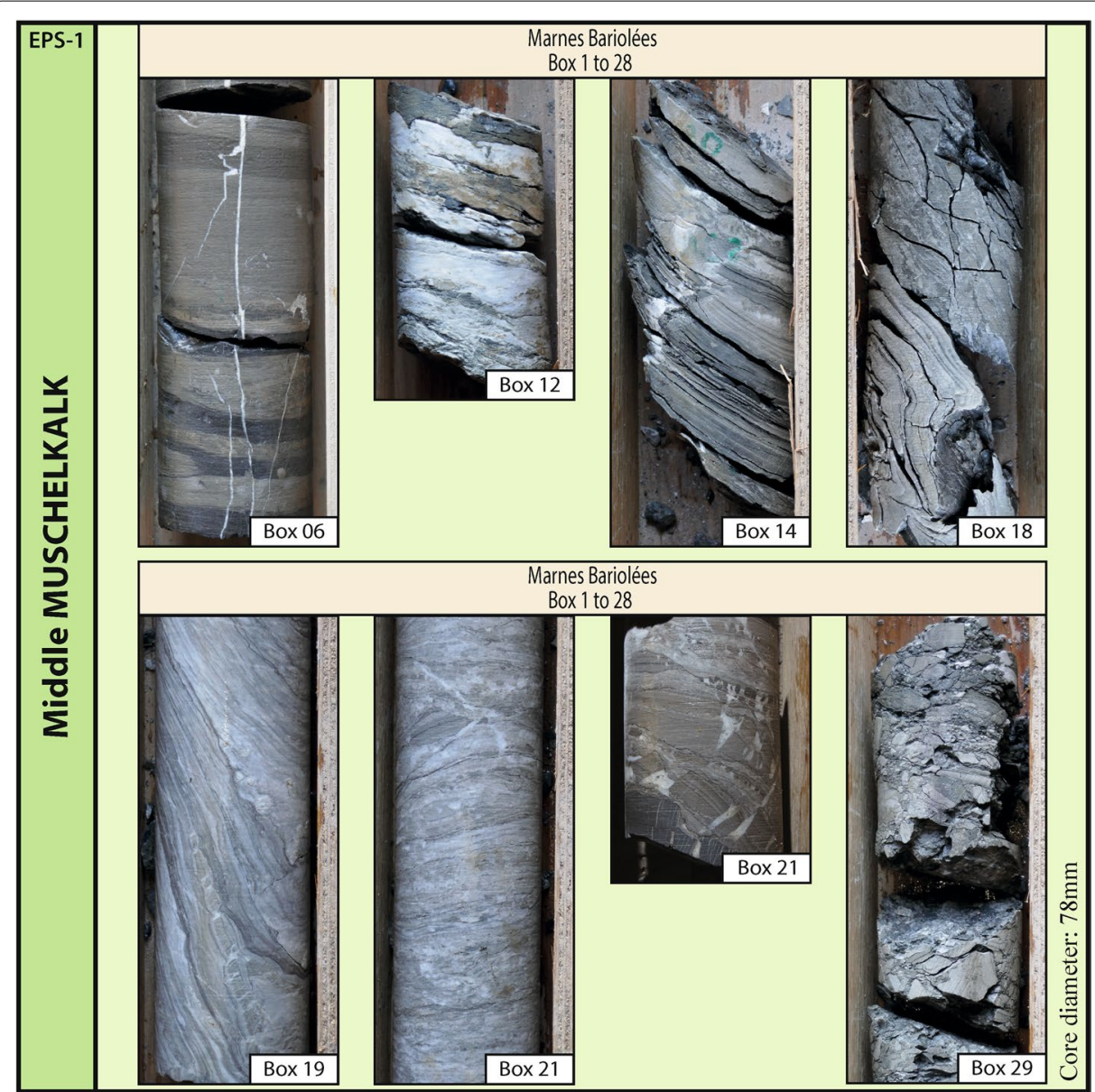

Fig. 3 Photo board of the cores from the middle Muschelkalk, with the Box associated with the cores; this package is correlated to a formation (with the name and boxes concerned). All the cores have a diameter of $78 \mathrm{~mm}$. All the boxes correspond to the Marnes Bariolées formation. Box 06 corresponds to dolomite alternating with dolomitic marl with sealed fractures nearly vertical (in white). Box 12 shows great amount of anhydrite layer (in white) in the dolomitic formation (gray). Boxes 14, 18, 19 and 21 corresponds to dolomite strongly folded, with fractures (in white in the Box 14 and 21). Box 29 corresponds to a hydraulic breccia with mineralized fractures

\section{Core observations}

The small-sized Myophoria orbicularis, the typical fossil that gives the name to the formation, has not been conclusively identified, and the typical spongy structure of the Schaumkalk expressed mainly in the field could not be characterized (Fig. 2). However, a massive continuous dolomite succession with rare marl content is typical of these beds (Fig. 5B30). The dolomite of around 6 meters of thickness consists of well-cemented dolomicrite to dolosparite (Fig. 5B35), together forming consistent unbroken massive cores that are relatively rare. In the country, from one place to another, according to the geochemistry composition (proportion of carbonate) the formation varies from Schaumkalk to Schaumdolomit. 


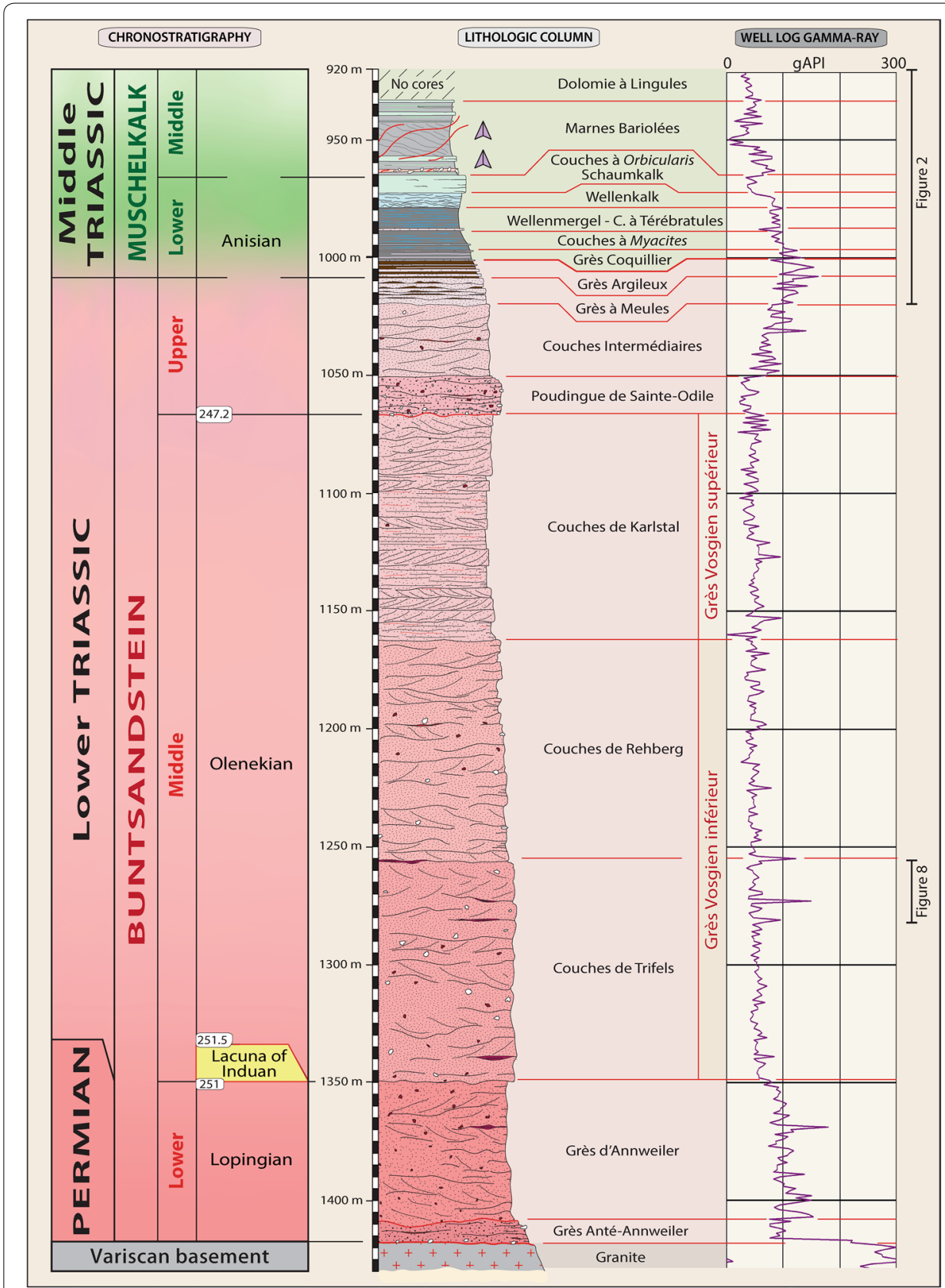

Fig. 4 Complete EPS-1 chronostratigraphic log from the middle Muschelkalk to the Variscan basement in front of the gamma-ray log acquired in the borehole. The limits between each formation are given jointly by the geological- and the GR log. Figure 2 (see preceding) represents the detail of the middle and lower Muschelkalk and upper Buntsandstein. Figure 8 represents the detail of the upper part of the Couches de Trifels formation. The violet arrow represents the occurrences of gypsum (same legend as in Fig. 2)

\section{Gamma-ray observations}

After the high radioactive signal at the base of the marly lower Marnes Bariolées, the GR signal strongly shifts to the left beginning at the contact of the formation with the occurrence of the massive dolomite bank; the signal remains unchanged over more than $10 \mathrm{~m}$, i.e., up to the base of the formation (Fig. 4). 


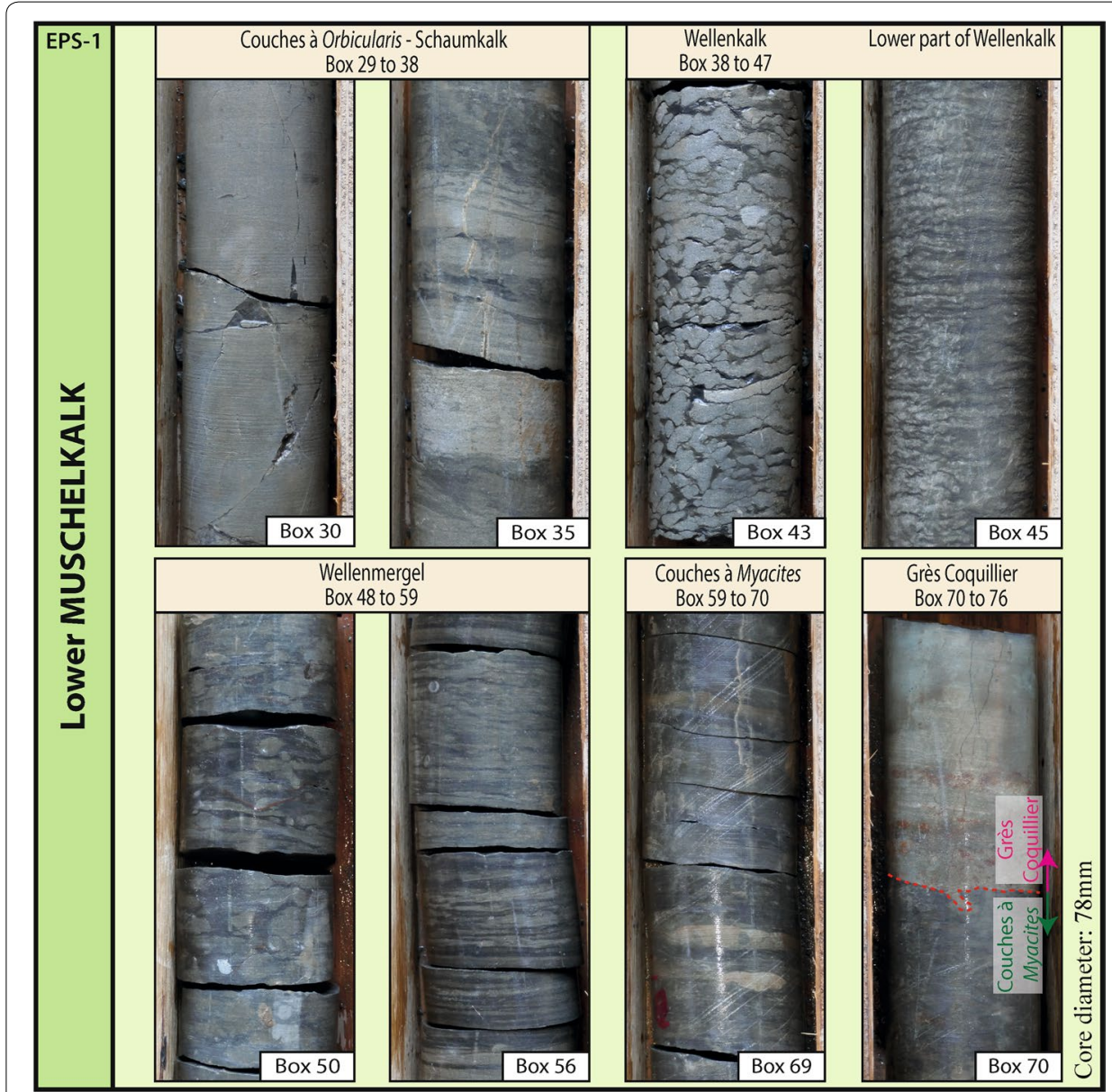

Fig. 5 Photo board of the cores from the lower Muschelkalk, with the Box associated with the cores; this package is correlated to a formation (with the names and boxes concerned). All the cores have a diameter of $78 \mathrm{~mm}$. Box 30 corresponds to the Couches à Myophoria Orbicularis composed of massive dolomite, alternating between dolomicrite and dolosparite, with marl content. Box 35 corresponds to the Schaumkalk composed of dolomite (generally dolomicrite) alternating with clays (in dark, wavy and bioturbated). Boxes 43 and 45 correspond to the Wellenkalk formation, where dolomite alternates with millimetric marls and silty marls, with the whole facies as wavy to lenticular bedding interpreted as tidal deposits. The lower part of the formation (Box 45) marks the passage from wavy to lenticular bedding. Boxes 50 and 56 correspond to the Wellenmergel formation, a centimeter-scale dolomite laminae interbedded with centimetric bioturbated marls. Box 69 corresponds to the Couches à Myacites formation composed of marls intercepted by fine dolomites, sandy dolomites, and sometimes sandstone beds. Box 70 corresponds to the Grès Coquillier composed of sandstones with few clayey and silty marls levels

\section{Wellenkalk (Wellendolomit)}

From the top of Box 38 to the Box 47, corresponding to depths of $971 \mathrm{~m}$ to $978 \mathrm{~m}$.

\section{Core observations}

The Wellenkalk facies, which means "wavy limestone" in English, is one of the most distinctive facies of the lower Muschelkalk (Fig. 2). It consists of around 7 meters of centimetric scale undulated limestone alternating with millimetric marls and silty marls. The whole facies is strongly reminiscent of what is described as wavy to lenticular bedding in many tidal deposits. The facies can be effectively interpreted as the stacking of mostly small wave to current ripples formed in very shallow water (Schwarz 1970) (Fig. 5B43). 
There are very few facies variations throughout the formation, other than the downward increase in the percentage of marls (passage from wavy to lenticular bedding) (Fig. 5B45), and the occurrence of bioturbation (potentially Planolites) giving to the facies a nodular appearance. According to the carbonate composition (calcite or dolomite), the name varies from Wellenkalk to Wellendolomit.

Gamma-ray observations

The great transition from the massive dolomite free of marls to the wavy bedding characterized by a relative enrichment in marls leads to an increase in the radioactivity and thus a shifting of the GR signal, first to the right and then, as the facies remains unchanged, more vertical line up to the base (Fig. 4).

\section{Wellenmergel and Couches à Térébratules}

From the Box 48 to the middle of Box 59, corresponding to depths of $978 \mathrm{~m}$ to $989 \mathrm{~m}$.

Core observations

The Wellenmergel facies, which means "wavy marls" in English, are similar to the Wellenkalk that occurs close to their contact, but they differ downward due to the rapid increase in marl content (Fig. 2). Otherwise, the dolomite facies is also very different. The ripple-like lenticular bedding of the former formation disappears rapidly on account of centimeter-scale dolomite laminae (without dominant characteristics) interbedded with centimetric marls, giving the facies its wavy appearance (Fig. 5B50). Some beds are often loaded, lateral pinch-out and strongly bioturbated (potentially Skolithos à Cruziana). The thickness of the carbonate beds as well as those of marls varies on average between 1 and $5 \mathrm{~cm}$ (Fig. 5B56). The two characteristics shell banks of Terebratula (upper and main banks) described by Schumacher $(1890,1891)$ as the "Terebratel Bank" in a scarce outcrop have not been identified, but shelly limestone has been observed from boxes 53 to 58; some has been identified as Terebratula. However, based on our outcrop observations (with for example Helstroff in Moselle), Terebratula often occurs without forming solid limestone banks that are strongly laterally discontinuous which is why we prefer to replace the term Calcaire à Térébratules with Couches à Tétébratules, largely dominated by marls. Some sandy dolomites and sandstones are observed in the cores, and a massive sandstone is observed in Box 59. It is not rare to find sandy dolomites and sandstones in the outcrops (the abandoned quarry of Diemeringen is the most beautiful example, at $45 \mathrm{~km}$ from Soultz-sous-Forêts). In EPS-1, these formations are $11 \mathrm{~m}$ thick.

\section{Gamma-ray observations}

From the top to the base of the Wellenmergel, even though the GR signal is slightly oscillating, it remains relatively stable as a vertical section (Fig. 4). Schumacher $(1890,1891)$ described two typical limestone banks rich in Terebratula called upper and main "Terebratel Bank" not identified in the EPS-1 cores (at Volmunster-Lengelsheim, $40 \mathrm{~km}$ of Soultz-sous-Forêts). However, as in the majority of other wells (e.g., OBR-101 at Oberroedern), a less radioactive signal at the base of the formation exists. Knowing that the main Terebratula bank described by Schumacher and located at the base can be very 
discontinuous and replaced locally by sandstone, we put the base of the formation at this level of the well underlined by a massive sandstone bank.

\section{Couches à Myacites}

From the middle of Box 59 to the middle of Box 70, corresponding to depths of $989 \mathrm{~m}$ to $996.60 \mathrm{~m}$.

\section{Core observations}

The fossil Myacites mactroides has not been identified with certainty in the cores, but the facies is sufficiently representative for the formation identification. In fact, the fossil characterizing this formation is also very difficult to find in the field. Concerning the facies, observed on the cores, it consists mainly of gray to black marls (yellow in the field) intercepted by fine dolomites, sandy dolomites, and sometimes sandstone beds (Fig. 5B69). The thickness of the marls and solid banks is highly variable. The former varies from $10 \mathrm{~cm}$ to $1 \mathrm{~m}$ and sometimes more; the latter is approximately $10 \mathrm{~cm}$, rarely more, in the well. The percentage of carbonate decreases from the top to the base of the formation (Fig. 2). The thickness of the Couches à Myacites is of around 8 meters thick.

\section{Gamma-ray observations}

The bottom of the formation occurs just before the sudden positive radioactive curve announcing the start of the Grès Coquillier. The Couches à Myacites, which have a thin thickness, do not display a significant signal, but from the top to the base, the GR signal generally displays a uniform increase in radioactivity (Fig. 4).

\section{Grès Coquillier}

From the middle of Box 70 to the middle of Box 76, corresponding to depths of $996.60 \mathrm{~m}$ to $1001 \mathrm{~m}$.

\section{Core observations}

The 4.4-m-thick formation consists of sandstones and dolomitic sandstones alternating with marly and silty clays (Fig. 2). The thickness of the sandstones varies from 10 to $40 \mathrm{~cm}$, and the thickness of the clays, from 20 to $80 \mathrm{~cm}$ on average. Based on only core observations, the difference between the Couches à Myacites and the Grès Coquillier is not always obvious close to the contact between the two formations. One of the best criteria is the increase in sandstone levels in the Grès Coquillier concomitant with the decrease in marls to more clayey and silty marls (Fig. 5B70). In the field, the facies can display many changes (the number and thickness of sandstone banks as well as the thickness of whole formation, linked to the partly deltaic environments) between quarries separated by over a few kilometers.

Gamma-ray observations

With only 4 meters of formation, the description of the GR signal is not evident. The top of the Grès Coquillier is easy to identify. It is characterized by the strongest positive signal observed since the beginning of this sequence, explained by the increase in both pure 
clays and micaceous sandstones (Fig. 4). The only additional feature that can be observed here is that the signal remains consistently stronger than before; the incursion to the left of the oscillations is due to the sandstone levels.

\section{Buntsandstein}

From the middle of Box 76 to Box 542, corresponding to depths of $1001 \mathrm{~m}$ to $1417 \mathrm{~m}$.

The Buntsandstein group is subdivided into eight formations (Perriaux 1961; Durand 1978, 2010; Gall, 1971, 1972, 1985; Dachroth 1985; Mader 1985; Ménillet et al. 2015) and entirely consists entirely of 450-m-thick continental, fluvially dominated red sandstone that is fine to coarse grained with frequent conglomeratic beds, especially at the base. However, some aeolian environments occur. The Buntsandstein is separated into three parts, upper, middle and lower. From the top to the base (Fig. 4), these eight formations are the Grès à Voltzia and Couches Intermédiaires in the upper Buntsandstein (Anisian), the Poudingue de Sainte-Odile, Grès Vosgien subdivided into Couches de Karlstal, Couches de Rehberg and Couches de Trifels in the middle Buntsandstein (Olenekian) and finally the Grès d'Annweiler and Grès Anté-Annweiler in the lower Buntsandstein. The last two belong to the Permian (Lopingian) but are included in eastern France to the Buntsandstein Group (Durand 2010; Ménillet et al. 2015).

\section{Grès à Voltzia}

From the middle of Box 76 to Box 97, corresponding to depths from $1001 \mathrm{~m}$ to $1019 \mathrm{~m}$.

Core observations

The Grès à Voltzia, approximately 18 meters thick, is composed (from the top to the base) of two units, the Grès Argileux and the Grès à Meules (Fig. 2). The former consists of micaceous sandstone and dolomitic sandstone alternating with green to red-colored clays and silty clays (Fig. 6B76). The latter consists of massive clayey sandstone banks with micaceous surfaces, light red or gray in outcrop, gray in deep drilling (Fig. 6B86 and B94). The subformation of the Grès à Meules is quite homogeneous in facies and thickness through the country, but this is not the case for the Grès Argileux, which displays huge lateral changes, from clay dominated to sand- or silt-dominated facies. In all cases, the Grès à Voltzia sandstones are fine grained from the top to the base. In EPS-1, the Grès Argileux is observed between $1001 \mathrm{~m}$ and $1008 \mathrm{~m}$ (Box 83); the Grès à Meules is observed between $1008 \mathrm{~m}$ and $1019 \mathrm{~m}$, for a total thickness of $18 \mathrm{~m}$. In the cores, the top of the Grès à Meules is characterized by the sudden arrival of massive sandstone beds, compared with the sandstone and dolomitic sandstone/clay alternations in the Grès Argileux. In the Grès à Meules, the sandstone banks can reach several meters and are separated by discontinuous centimetric to decametric clay layers.

Gamma-ray observations

Muschelkalk is characterized by the constant increase in the natural radioactivity toward the bottom of the series, which is directly linked to a constant increase in the clay content (Fig. 4). The top of the Grès Argileux (upper Grès à Voltzia) is characterized by a less radioactive peak followed seven meters below by a very strong radioactive peak, 


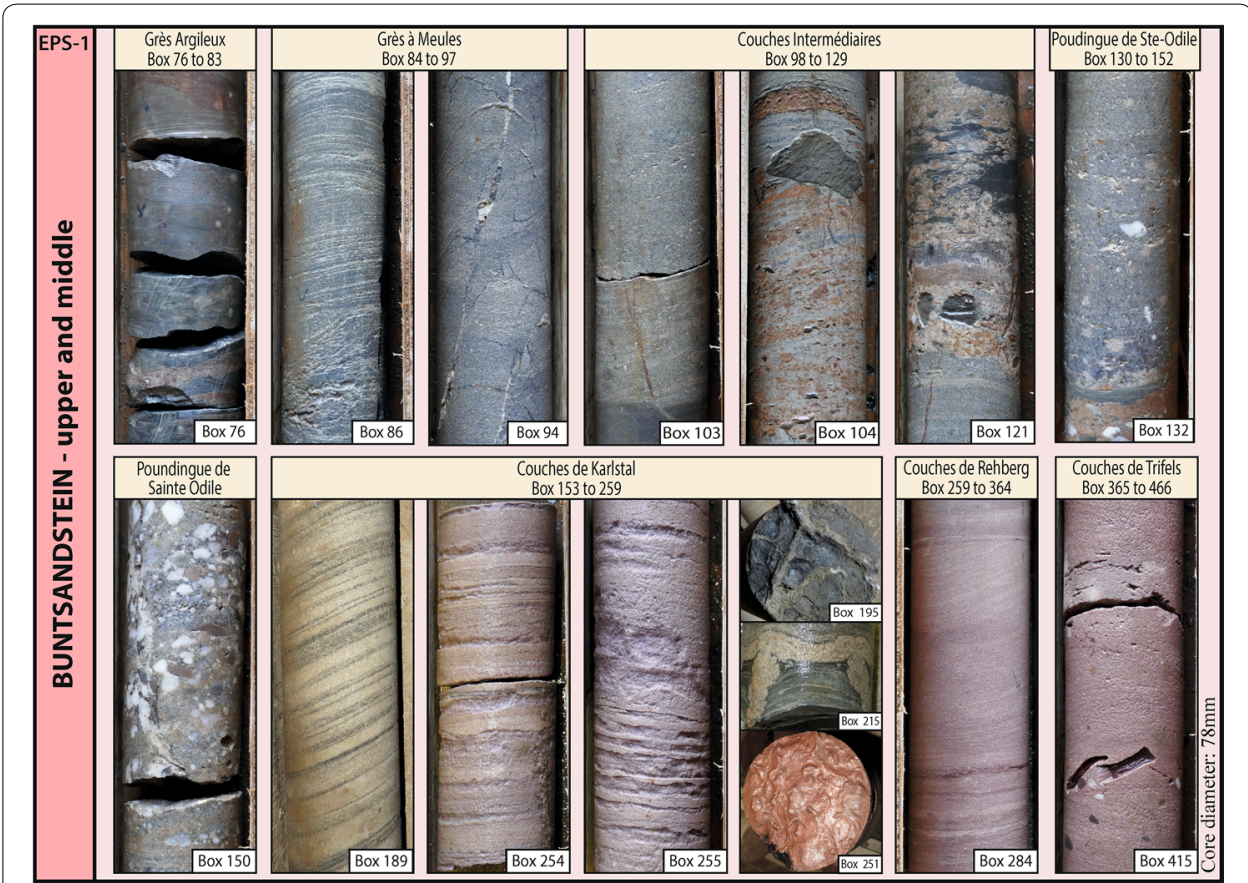

Fig. 6 Photo board of the cores from the upper and middle Buntsandstein, with the Box associated with the cores; this package is correlated to a formation (with the names and boxes concerned). All the cores have a diameter of $78 \mathrm{~mm}$. Box 76, Grès Argileux (upper Grès à Voltzia) composed of micaceous sandstone and dolomitic sandstone alternating with green to red-colored clays and silty clays. Boxes 86 and 94, Grès à Meules (lower Grès à Voltzia) composed of massive clayey sandstone banks with thin micaceous surfaces. Are observed in the Box 96 oblique beddings. In the Box 94, occurrence of nearly vertical fractures, filled with white barite. Boxes 103, 104 and 121, Couches Intermédiaires composed of coarse-grained sandstones with oblique beddings (Box 103 and Box 104) alternating with red to purplish clays and silty clays, with numerous rip-up mud clasts and oxidations zones. Boxes 132 and 150, Poudingue de Sainte-Odile composed of coarse-grained sandstone to true conglomerate, with mostly rounded white milky quartz pebbles and very fine-grained red quartzites. Boxes 189, 195, 215, 251, 254 and 255, Couches de Karlstal: this formation presents two distinct facies with planar sandstone beds alternating with horizontally stratified fine silty clay lamina (milli- to centimetric scale) (Box 254 and Box 255) interpreted as typical playa facies with many desiccation cracks (Box 195 and Box 215), wind/wave ripples and small bioturbations (Box 251). The second facies consists of large oblique tabular and trough cross-beds (Box 189), which looks like aeolian dunes shape. Box 284, Couches de Rehberg composed of coarse-grained sandstones with large cross-beddings. Box 415, Couches de Trifels: medium- to coarse-grained sandstones with various mud clasts (sometimes imbricated and formed by desiccation cracks)

which is the highest value along the entire Triassic sedimentary column. This highest peak characterizes the summit of the Grès à Meules, which could be related to the presence of radioactive minerals (probably in zircon) in the sole of the transgressive phase of the Grès Argileux, which is often described as a transgressive series (see Duringer et al. 2019). Progressing downwards through the entire Grès à Voltzia, the GR signal decreases progressively as the clayey sandstones disappear, marking the passage between the Grès Argileux and the massive Grès à Meules. Within the Grès à Meules, the signal consistently has wide right/left oscillations (high amplitude, low frequency for the interbedded clays) until it reaches a less radioactive plateau that characterizes the summit of the Couches Intermédiaires. 


\section{Couches intermédiaires}

From Box 98 to Box 129, corresponding to depths of $1019 \mathrm{~m}$ to $1050.5 \mathrm{~m}$.

Core observations

The Couches Intermédiaires are 31.5 meters thick. Formed by slightly coarser sandstones that are more reddish, the series is generally less micaceous and less clayey rather than Grès à Voltzia. Oblique bedding (Fig. 6B103 and B104), medium to fine grained, can be observed on meter-scale sets. In outcrops, channels are frequent. In the Grès à Voltzia, the sandstone strata alternate with centimetric to pluridecimetric red to purplish clay and silty clay levels. Dolomitic concretions of boulder size (paleosols), numerous rip-up mud clasts, and manganiferous and ferrous oxidation zones with occasional Liesegang rings are common. The lack of pebbles in general characterizes the upper and middle parts of the Couches Intermédiaires (Fig. 6B121). In its lower part, one observes an increase in the grain size up to, in some places, enriched pebbly zones (mainly milky quartz and quartzite pebbles) announcing the passage to the following formation: the Poudingue de Sainte-Odile (Ménillet et al. 1989, 2015). If the clay banks in the Grès à Meules vary from light red to green, in the Couches Intermédiaires, these banks are always red to dark red.

Gamma-ray observations

As described above, the Couches Intermédiaires can be divided into two sections: an upper part with clay alternations, similar to the overlying Grès à Meules, and a lower part that is more massive and often coarse-grained. Both sections can be observed in the gamma-ray signal, with a frequency that is higher in the upper part rather than in the lower part. Despite this, the GR signal decreases continuously downwards from the Grès Argileux with right/left oscillations that are less well expressed. This is due to the progressive decrease in clay content (Fig. 4).

\section{Poudingue de Sainte-Odile}

From Box 130 to Box 152, corresponding to depths of $1050.5 \mathrm{~m}$ to $1064.5 \mathrm{~m}$.

\section{Core observations}

In most of the country, the Couches Intermédiaires overlies a prominent conglomeratic formation called the Poudingue or Conglomérat de Sainte-Odile; it is sometimes also called Conglomérat Principal, but that name is less used now. This latter formation is a conglomerate spreading for hundreds of kilometers from the Paris Basin (SSW) to Germany (NNE). Real marker beds are found in the middle and southern part of the Vosges; the Poudingue de Sainte-Odile seems poorly developed in the northern part of the Vosges or is even completely absent, according to Durand (2010). Approximately twenty meters thick, the formation displays an almost continuous prominent ridge in the landscape. The conglomerate is mainly composed of milky quartz and very fine-grained pink quartzite pebbles. Lydian pebbles rarely occur (Perriaux 1961). From the cores (EPS-1 well), it is observed that the proportion of pebbles is much lower than expected; most intervals are closer to coarse-grained sandstone bodies with scattered pebbles rather than to true conglomerates (Fig. 6B132). 
According to Durand (2010), the Poudingue de Sainte-Odile does not exist in most sectors in the northern part of the Vosges (approximatively $15 \mathrm{~km}$ northeast from Haguenau). This absence could be the result of significant erosion, the surface of which was named by Trusheim (1961) as the "Hardegsen Diskordanz". The new deposits on this surface of erosion on the top of the Grès Vosgien belong, according to Durand (2010), to the new cycle of the Couches Intermédiaires whose base is conglomeratic. Durand (2010) calls this new conglomerate distinct from the Poudingue de Sainte-Odile, the Conglomérat de Grosbliederstroff (Ménillet et al. 2015). According to Bourquin and Durand (2007), the existence of the conglomerate of Grosbliederstroff is defined by two key criteria. First there is the presence of small immature pebbles and the occurrence of carnelian clasts (reworked clasts of the top of Poudingue de Sainte-Odile, which were deposited after a long time without deposition that allowed the development of a paleosol called Zone Limite Violette (ZLV)). This ZLV area was described by Müller (1954a), (b), (c), who first carried out a complete study in the Saar region of Germany and gave it a name that suits perfectly because even if some places do not contain any dolomite or carnelian, they still retain the typical violet color (Perriaux 1961). The ZLV is linked to a subaerial weathering episode (Durand, 2010, 2013; Ménillet et al. 2015; Müller 1954a, b, c) corresponding to a complex of dolocrete and silcrete palaeosoils that developed on top of the Poudingue de Sainte-Odile, in a less arid climate (Durand 2010). Then, according to Durand (2010), the building of a new detrital sequence after this long period of subaerial weathering started with a new conglomeratic unit that forms the Conglomérat de Grosbliederstroff in place of the eroded Poudingue de Sainte-Odile. So, in the northern part of the Vosges, this conglomeratic unit occurs between the Couches de Karlstal (Grès Vosgien supérieur) and the Couches Intermédiaires.

After observing the cores of the EPS-1 well at Soultz-sous-Forêts, the question remains whether the observed conglomeratic zone is the distal termination of the Poudingue de Sainte-Odile or the Conglomérat de Grosbliederstroff? In the case of the erosion hypothesis, the carnelian clasts would appear in the cores. For the hypothesis of a northern distal part of the Poudingue de Sainte-Odile sequence, there would be an important decrease in the pebble proportion which is observed in the core of EPS-1, characterized by mainly very scattered pebbles at approximately $1050 \mathrm{~m}$ and $1070 \mathrm{~m}$ (Fig. 6B132 and B150). Even if the pebbles of the Poudingue de Sainte-Odile are characteristic and the majority have a high degree of maturity, smaller, more angular pebbles are also observed, since we also consider the smaller part of the pebbles and gravels. In the case of distal termination, at the end of the sequence, only the small clasts would be deposited (the decrease in energy far from the source), as demonstrated by the pebbles observed in the EPS-1 cores. A total absence of carnelian clasts in the cores is noticed. Moreover, even if the formation is poor in pebbles, the overall observed thickness of this quite conglomeratic zone is equivalent to the thickness of the Poudingue de Sainte-Odile, whenever it exists southward. Therefore, in the case of the EPS-1 cores, the conglomeratic zone observed between the Couches Intermédiaires and the Couches de Karlstal is interpreted as representing the Poudingue de Sainte-Odile. 
Gamma-ray observations

Whether the formation belongs to the Poudingue de Sainte-Odile or the Conglomérat de Grosbliederstroff remains questionable, the GR signal is strongly representative. It presents two broad curve-shaped signals, with a great decrease in the value at the transition between the Couches Intermédiaires and this conglomeratic zone. Afterward, the value at the base increases (the beginning of the Grès Vosgien) (Fig. 4). With fewer variations in frequency and amplitude, the signal is smoother over this conglomeratic part. At the middle of the signal, an increase in the value is observed (which makes the signal look like an ' $\mathcal{E}$ '). Due to older sampling, some cores are missing around that depth, which could coincide with clay banks and would explain the increase in the GR value. Indeed, in the Poudingue de Sainte-Odile, from the top to the bottom, the conglomeratic facies alternates with more sandstone facies or even clayey sandstones.

Considering the question of whether the formation is the Poudingue de Sainte-Odile or the Conglomérat de Grosbliederstroff, in the EPS-1 well, the GR signal brings an important clue: the intensity of the signal and its general shape as well as the thickness of the formation are similar, point to point, to the GR signal of the Poudingue de SainteOdile south of Strasbourg (e.g., MEI-2; Meistratzheim), where its occurrence is indisputable (Aichholzer, 2019). This conglomeratic zone of approximately twenty meters at the same chronostratigraphic position has also been observed in all the geothermal wells of Soultz-sous-Forêts (GPK) and Rittershoffen (GRT) (Fig. 1).

\section{Grès Vosgien}

From Box 153 to Box 466, corresponding to depths of $1064.5 \mathrm{~m}$ to $1349 \mathrm{~m}$.

\section{Core observations}

The cores show facies variations in the Grès Vosgien, even if, objectively, the variations are not evident enough to set a sublimit as it was defined for the first time in Germany by Leppla (1888) and Thürach (1894). Regarding the French nomenclature Grès Vosgien supérieur and Grès Vosgien inférieur, the Couches de Karlstal belongs to the former, while both the Couches de Rehberg and Couches de Trifels belong to the latter (Ménillet et al. 2015). The GR synthesis will be given after the core descriptions of each unit composing the Grès Vosgien.

Couches de Karlstal From Box 153 to the middle of Box 259, corresponding to depths of 1064.5 to $1161 \mathrm{~m}$.

The Couches de Karlstal (Grès Vosgien supérieur) consists of sandstone that is coarser than the two overlying sandstone units: the Couches Intermédiaires and the Grès à Voltzia. In the cores, the thickness of the formation is $96.5 \mathrm{~m}$ in the well. The thickness can reach $120 \mathrm{~m}$ in the field and is divided at the middle (of the two intervals) by a harder bank, usually conglomeratic, though it is not identified with certainty in the well. With a thickness of approximately 20 meters, this level represents the recurrence of facies as massive banks with planar cross-stratification to trough cross-stratification, which are predominant in the Couches de Trifels (Grès Vosgien supérieur) (Ménillet et al. 1989, 2015). 
From pink to reddish brown, the Couches de Karlstal forms multimetric beds. There are two distinct facies in the Couches de Karlstal (Figs. 6, 7b). The first facies, observed in the cores, is composed of planar sandstone beds alternating with horizontally stratified fine silty clay lamina (milli- to centimetric scale) (Fig. 6B254 and B255). This centimetric alternation of sandstone and silty clays is typical of playa facies from the Couches de Karlstal. It is in this medium- to coarse-grained facies that many desiccation cracks, wind/wave ripples and small bioturbations can be observed (Fig. 6B195; B215 and B251). In this playa type, sediments alternate with coarser, poorly cemented sandstone, with strong, spherical smoothed and frosted grains: named "caviar-like" facies. This aeolian facies forms multidecimetric to plurimetric sets that are poorly cemented, and the size of these rounded grains varies between 0.5 and $1 \mathrm{~mm}$ (Dachroth 1985; Durand 2010). In the field, this lithofacies consists of large oblique tabular and trough cross-beds that look like aeolian dunes shape (Fig. 6B189). In the EPS-1 cores, the presence of mud chips and pebbles generally less than $3 \mathrm{~cm}$, usually in place in "regs like" layers, are observed in the upper part of the sandstones, which are impregnated with oil. The "caviar-like" facies sandstone (Fig. 7b, B241) is observed in the two different aeolian facies described above.

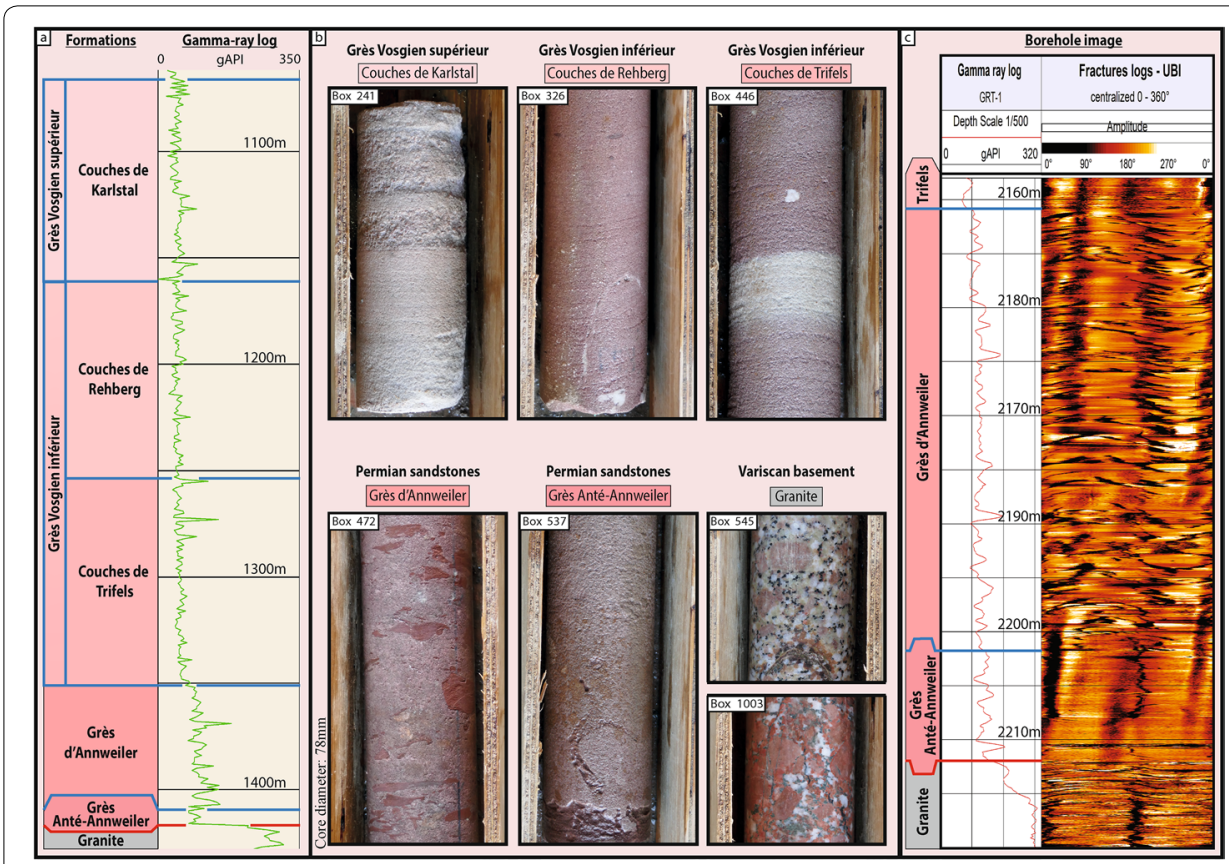

Fig. 7 a EPS-1 gamma-ray log between the Couches de Karlstal and the Grès Anté-Annweiler showing the limits and $\mathbf{b}$ cores from EPS-1 from the middle Buntsandstein to the Variscan basement. Box 241: "caviar-like" facies sandstone typical from the Couches de Karlstal. Box 326, Couches de Rehberg: coarse sandstone with white quartz pebbles and a filled fracture (white circular arc). Box 446, Couches de Trifels: coarse-grained sandstone with white quartz pebbles and a decolored level. Box 472, Grès d'Annweiler: clayey sandstone with high frequency rip-up clay clasts of all sizes rounded or angular. Box 537, Grès d'Anté-Annweiler: coarse-grained clayey arkosic sandstones with a thick clay level at the base. Boxes 545 and 1003, Variscan granitic basement: unaltered monzogranite with K-feldspar megacrystals and oxidized facies, respectively. c GRT-1 GR log and borehole image log showing unrolled vertically compressed image of the sedimentary cover-basement transition in GRT-1. This acoustic log presents the amplitude data, highlighting natural fractures (Grès d'Annweiler) and induced fractures (Grès Anté-Annweiler) 
Couches de Rehberg From the middle of Box 259 to Box 364, corresponding to depths of $1161 \mathrm{~m}$ to $1256 \mathrm{~m}$.

The Couches de Rehberg (Grès Vosgien inférieur), approximately one hundred meters thick, consists of very coarse sandstones with large cross-bedding (Figs. 6, B284; 7b, B326). At the top of the formation, numerous brown ferromanganese patches called Grès tigrés ("Tiger sandstones"), mud clasts and some clayey layers occur. At the base of this formation, coarser sandstones with scattered pebbles and some micaceous beds appear. In the field, this formation shows conglomeratic thin intervals. The Couches de Rehberg are very similar in facies to the Couches de Trifels, which makes their distinction difficult based only on cores (and cuttings) analysis.

Couches de Trifels From Box 365 to Box 466, corresponding to depths of $1256 \mathrm{~m}$ to 1 $349 \mathrm{~m}$.

The Couches de Trifels (Grès Vosgien inférieur) consists of medium- to coarse-grained sandstones that frequently embed scattered quartz pebbles throughout the formation, as well as mud clasts (Figs. 6B415; 7b, B446). Cross-bedded facies are frequent. At around $90 \mathrm{~m}$ thick, the formation has a pink to red-brown color. The top of the unit contains three characteristic silty and micaceous clay beds, each twenty centimeters thick (Fig. 8). The first marks the upper contact with the Couches de Rehberg. These three horizons of silty clays of few meters of thickness were also found in the GRT-1 well (Rittershoffen, $7 \mathrm{~km}$ away from Soultz-sous-Forêts, Fig. 1), so we can consider that their extent is almost regional and therefore can regard them as a marker for the upper part of the Couches de Trifels.

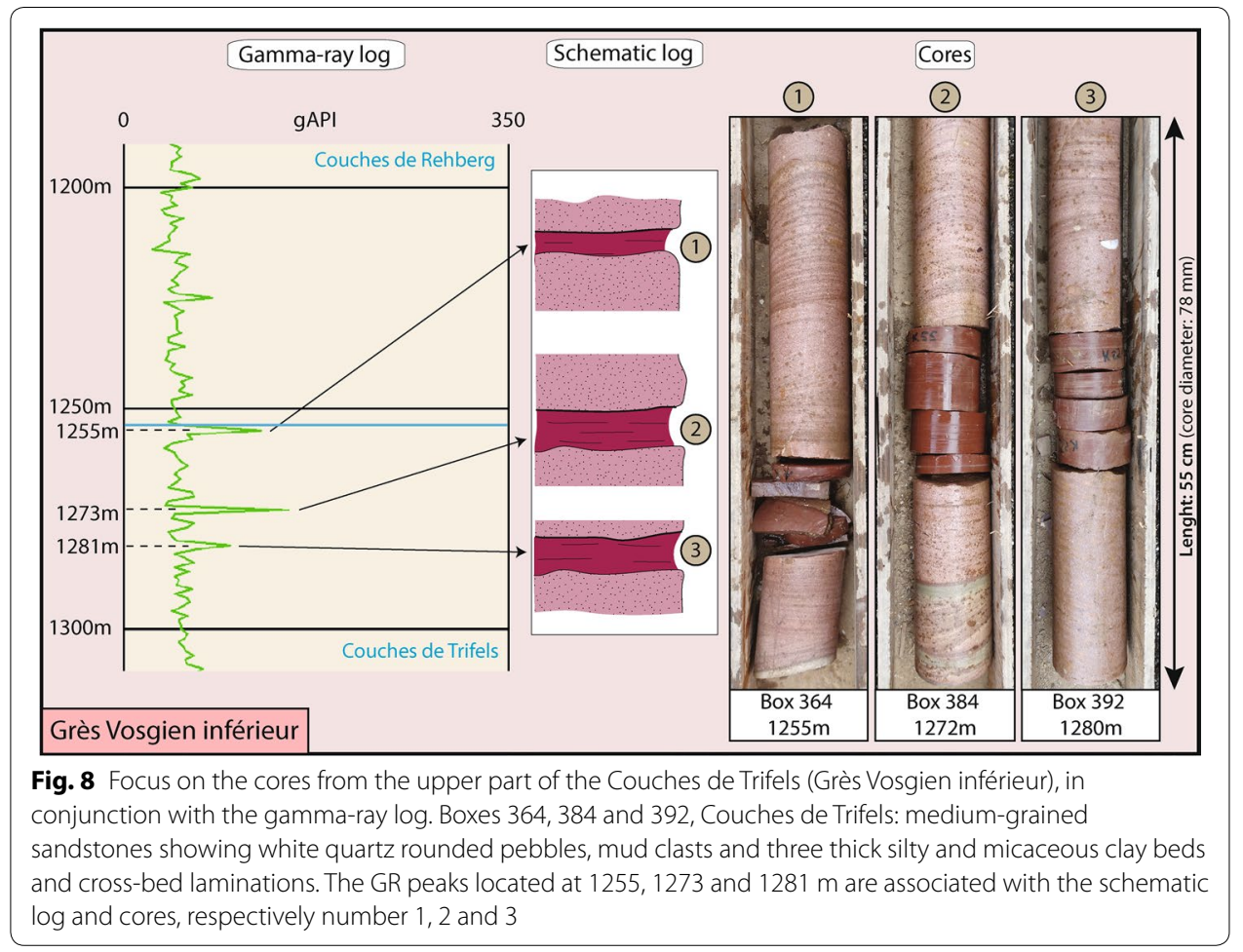


Gamma-ray observations for all the formations of the Grès Vosgien

The three formations that comprise the Grès Vosgien-the Couches de Karlstal, Couches de Rehberg and Couches de Trifels (from top to base, respectively)-are very close to each other in terms of the GR signal. As observed in the field or in the cores, these formations are sandstones composed of silica sand, and the main difference is the grain size and, therefore, the abundance of clays and clay levels. In most parts of the URG, the formations are just defined as the Grès Vosgien because of these similarities. Therefore, these similarities also explain why the GR signal is homogeneous and quite linear, with the same value within approximately 50 gApi (Figs. 4, 7a). The upper limit of the Grès Vosgien, just below the conglomeratic Poudingue de Sainte-Odile, is easy to observe from the GR signal. Moving downward from a low value in the Poudingue de Sainte-Odile, the signal jumps to the right, with a higher value and a signal that shows greater amplitude and frequency; in contrast, the signal is smooth and more regular in the Poudingue de Sainte-Odile.

Although the GR is quite similar throughout the Grès Vosgien, the upper part, corresponding to the Couches de Karlstal, is slightly different from the signals of both underlying formations. They are close to each other in terms of facies and, therefore, in terms of their well-log signal, with quite a constant amplitude and frequency. However, the Couches de Karlstal shows little variation (even if linear in the first order) with amplitude and frequency variations, which could be attributed to the differences observed in the cores between the two main types of facies (playa and aeolian).

Another substantial GR response, in the linear Grès Vosgien, can be found in Couches de Trifels because it is underlined by a thick clay bank. Due to their compositions and potassium-rich minerals (especially illite; Clauer et al. 2016), these three banks of clay are very well emphasized in the GR log because it forms three peaks with a pronounced shift to the right (the radioactive pole) (Figs. 4, 7a, Fig. 8). Observed in the box's core at depths of $1255 \mathrm{~m}, 1272 \mathrm{~m}$ and $1280 \mathrm{~m}$, these clays were detected by the GR sensor at depths of $1255 \mathrm{~m}, 1273 \mathrm{~m}$ and $1281 \mathrm{~m}$ (Fig. 8).

\section{Grès Permien}

From Box 467 to Box 542, corresponding to depths of $1349 \mathrm{~m}$ to $1417 \mathrm{~m}$.

Core observations

After Durand (2010) and Ménillet et al. (2015), the Grès d'Annweiler belongs in eastern France in the Buntsandstein Group but is included to the uppermost Permian (Lopingian), which can bring a lot of trouble because Buntsandstein is defined in the international chart as lower Triassic (Induan to Anisian). In Soultz-sous-Forêts, the Grès Permien is composed of the Grès d'Annweiler and Grès Anté-Annweiler (lower Buntsandstein). The GR synthesis will be given after the core descriptions of the two formations.

Grès d'Annweiler From Box 467 to Box 532, corresponding to depths of $1349 \mathrm{~m}$ to 1 $408 \mathrm{~m}$.

Compared to the formations of the Grès Vosgien, the Grès d'Annweiler, $59 \mathrm{~m}$ thick is of finer lithology, mainly of fine to very fine grain size. On average, the size of the grains can 
be divided into two classes, sometimes more. The mean diameter of the grains oscillates between 0.1 and $0.3 \mathrm{~mm}$, while in the Grès Vosgien inférieur, the diameter is between 0.2 and $0.5 \mathrm{~mm}$. The Grès d'Annweiler is a clayey sandstone of red brick color. Overall, it is very homogeneous, but some coarse beds occur locally (Fig. 9B516 and B525). Except for the red color, the facies is very similar to the sandstone of the Grès à Voltzia. Based only on field or core samples, it remains impossible to differentiate those formations from light-colored samples. Some milli- to decimetric clay beds alternate with the sandstone (Fig. 9B496). The best criteria are both the numerous traces of bioturbations (very rare in the Grès Vosgien) and the high frequency of clay rip-up clasts of all sizes, which are rounded, more angular or related to true desiccation plates (Figs. 7B472, 9B478 and B505). There are also numerous nodules of dolomite and manganese oxide stains (concentrated in some areas) (Fig. 9B516). By contrast, the pebbles always present in the Grès Vosgien disappear at the boundary of this formation. The stratification is flat to slightly oblique. This latter formation alternates with more coarse sandstones

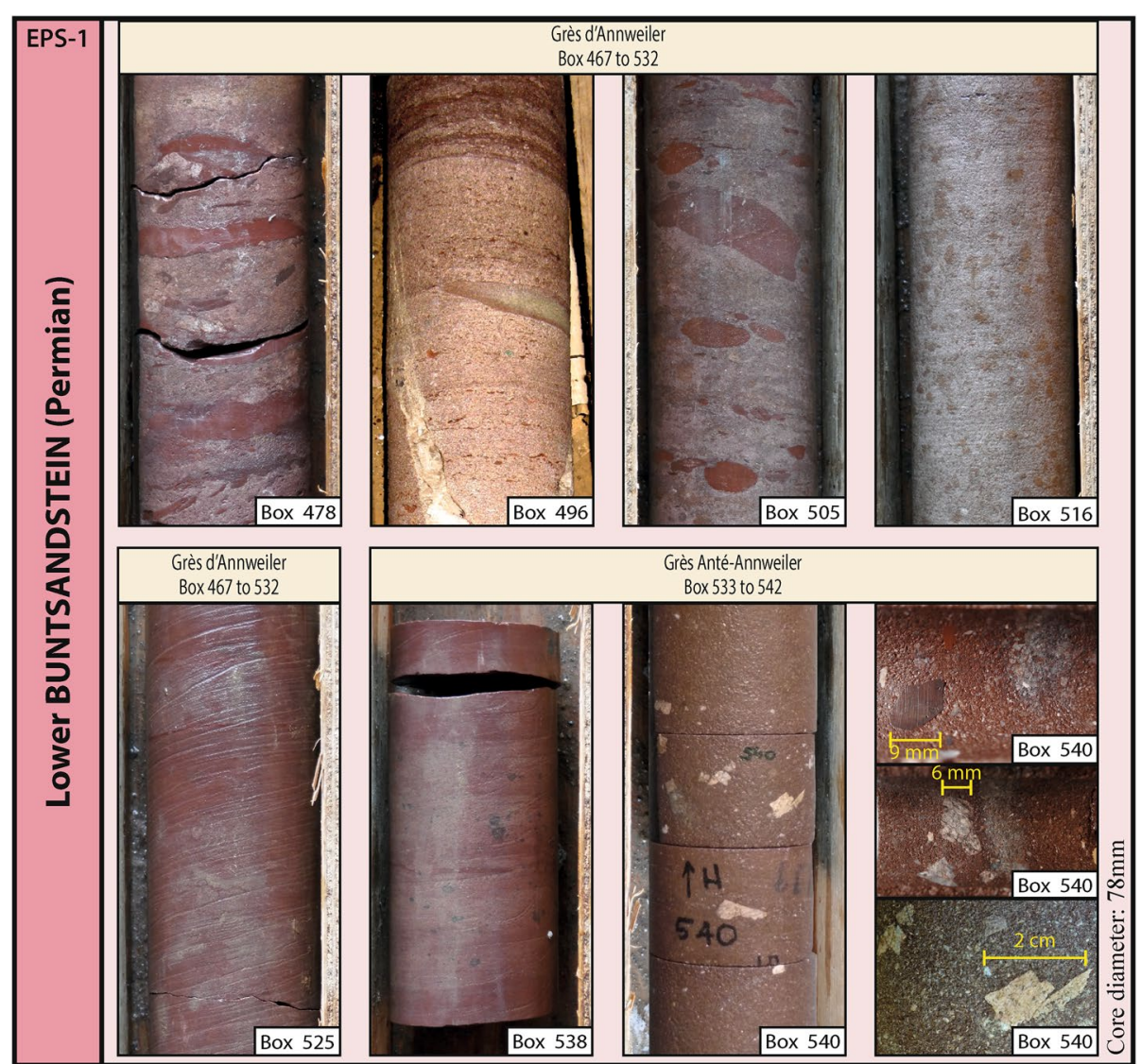

Fig. 9 Photo board of the cores from the lower Buntsandstein (Permian age), with the Box associated with the cores; this package is correlated to a formation (with the names and boxes concerned). All the cores have a diameter of $78 \mathrm{~mm}$. Boxes 478, 496, 505, 516 and 525, Grès d'Annweiler: clayey sandstones with very high frequency of clay rip-up clasts of all sizes rounded and angular (related to desiccation plates) and thin clay banks. A filled fracture with barite is observed in the Box 596. Boxes 538 and 540, Grès d'Anté-Annweiler: medium to coarse clayey sandstones with feldspathic megacrystal clasts (up to $2 \mathrm{~cm}$ ) and numerous Variscan basement clasts such as rhyolite $(9 \mathrm{~mm})$ and granite $(6 \mathrm{~mm})$. The difference of color with Box 496, compared to the others, is linked to the fact that the photo is coming from another shooting 
(sometimes similar to the sandstone of the Grès Vosgien), which are obliquely bedded and still very rarely contain pebbles.

Grès Anté-Annweiler From Box 533 to Box 542, corresponding to depths of $1408 \mathrm{~m}$ to $1417 \mathrm{~m}$.

The Grès Anté-Annweiler (Fig. 4) is a transitional formation between the basement and the Grès Permien. It is composed of dark red mostly coarse-grained arkosic sandstones (Fig. 9B538). Unlike the previous Permian formation, there are no more mud clasts and far fewer clay benches (Fig. 7B537). Nevertheless, there are scattered milky quartz pebbles and brown to blackish oxidation spots. In the field, microconglomerate zones are locally observed as tuff and volcanic ashes. The Permian formation observed in the cores is only approximately nine meters thick. As the base of the formation lies just above the granitic basement (Fig. 7B545 and B1003), some immature granite pebbles and feldspathic megacrystal clasts are observed (Fig. 9B540).

\section{Gamma-ray observations}

Easily recognizable in the field or in the cores, the Permian sandstones are generally made by clayey fine-grained sandstone, rich in clay intervals. They contain numerous rip-up mud clasts and are highly bioturbated. Therefore, due to a high percentage of clays, the contact between the Grès Vosgien and the Grès d'Annweiler is also easily recognized in the GR signal. Thus, the transition between the Grès Vosgien and the Permian formations is marked by a sudden shift to the right (radioactive high values) of the GR signal after the very vertical linear signal from the Grès Vosgien (Figs. 4, 7a).

Another interesting change in the GR is noticed between the Grès d'Annweiler and the Grès Anté-Annweiler. Indeed, the GR shifts slightly to the left and is less radioactive because of the decrease in the clay percentage, together with a grain size increase between both formations (Figs. 4, 7a). However, this signal is higher than the one observed in the Grès Vosgien because despite the low clay content (compared to the Grès d'Annweiler), it still remains higher than that in the Grès Vosgien. This signal is attributed to the fact that the Permian facies is more feldspathic (K-rich) and that the matrix of these sandstones is more clayey than the pure siliciclastic Triassic sandstones. It contains relics from the granitic basement and is, therefore, more radioactive because of high potassium (K), thorium (Th) and uranium (U) in the feldspars and granite clasts.

During the drilling phase, the identification of the contact between the sedimentary cover and the Variscan basement (Fig. 7a) remained complicated; based only on observations of the cuttings, the difference between the crushed, reddish, altered granite and the feldspar-rich arkose is very subtle and challenging (Fig. 9B540). However, the GR is undeniably associated with the presence of all the radioactive minerals in the basement, and the GR signal unquestionably gives the exact position of the Permian/Variscan boundary, with the largest jump to the right in the log at the top of the granite (Fig. 47a).

Based on acoustic image logs, it is also possible to spatially correlate the gamma-ray curve with the lithology at the transition between the sedimentary cover and the granitic basement (Fig. 7c). This detailed correlation is especially useful for boreholes drilled in rotary mode, which is the more standard case for deep wells. In that context, cutting examination could be interpreted in terms of arkose facies or reddish altered granite. It 
is really difficult to distinguish between a real arkose facies of sedimentary origin and a paleo-weathered granite. For example, in the neighboring geothermal well GRT-1 located at Rittershoffen (Fig. 1), a detailed comparison of GR logs and image logs allows the visualization of the different lithologic facies with depth. In the upper part, between 2161 and $2202 \mathrm{~m}$, the image logs show sedimentary facies with an abundance of local natural fractures (strong amplitude image), which geologically corresponds to the Grès d'Annweiler (Fig. 7c). From 2202 to 2212 m, the image logs show a massive rock with the presence of vertical induced fractures that correspond to the basal Permian formation, the Grès Anté-Annweiler. Finally, deeper than $2212 \mathrm{~m}$ depth, a darker image shows natural sinusoidal traces corresponding to steeply dipping natural fractures that characterize the Paleozoic fractured basement (Genter and Traineau 1996). In this section, it is also clearly visible that the GR curve increases from 150 to 300 gAPI due to the occurrence of radioactive minerals in the granite (primary biotite, K-feldspar megacrystals, and secondary clays such as illite ...). Therefore, the combination of the GR log and the high-resolution image logs calibrated by the cutting samples is a powerful tool for understanding the different lithofacies lying at the transition between the sedimentary cover and the granitic basement.

\section{Application of lithostratigraphic results to new geothermal projects}

This section highlights how fine resolution geological observations calibrated on highquality cores could contribute to secure the development of new geothermal projects in the URG. High-quality observations done in terms of lithostratigraphy on the EPS-1 cores and representative outcrops were used in several geothermal projects under development in the URG, like Rittershoffen and Illkirch, close to Soultz-sous-Forêts and Strasbourg, respectively. These main achievements were applied to ongoing industrial geothermal projects based on this geological approach. Important geological observations in the Triassic layers such as the occurrences of a given clay layer in the Buntsandstein sandstones or a well-known limestone bench in the Muschelkalk are very useful during drilling. For example, during drilling operations in Rittershoffen, the casing shoe of the liner installed after drilling of the $12 \frac{1 / 4}{4}$ section was laid on the Upper Buntsandstein in the Grès à Meules (Baujard et al. 2017). Then, the cuttings' examination during drilling was interpreted in terms of lithostratigraphical units. The precise depth of the casing shoe was decided on the basis of the daily geological profile produced and calibrated with the knowledge gained from the EPS-1 cores (Duringer et al. 2019). The use of the lithostratigraphic column for setting the casing was, therefore, applied to the two successful Rittershoffen geothermal wells (Baujard et al. 2017).

More recently, the drilling of the geothermal well GIL-1 in Illkirch, also benefited from both the detailed lithostratigraphic column and the use of LWD (Logging While Drilling) technology. Gamma-ray data were collected by LWD and then compared systematically to the specific signature of GR logs known in adjacent wells or from EPS-1. The comparison between the Soultz geothermal wells, the Rittershoffen wells and many old wells drilled in the Strasbourg area leads to the conclusion that the Triassic layers of Muschelkalk and Buntsandstein are isopach (Aichholzer et al. 2016).

This information is also very useful during drilling for forecasting the predictive geological section. For example, in the recent Illkirch well, the decision that led to 
the precise depth for setting the casing shoe of the liner was also successfully derived from the lithostratigraphic log calibrated with the LWD gamma-ray log. These kinds of isopach properties of the Triassic layers in Northern Alsace were used to forecast geological formations during a geothermal exploration phase in the Strasbourg area. Several 2D seismic profiles were interpreted using constant thickness values for Buntsandstein, Muschelkalk and Keuper (Richard et al. 2016). A 3D geological model taking into account various boreholes and vintage 2D seismic profiles was also built using this isopach rule for those sedimentary layers of Trias (Maurer et al. 2016). In the coming years, it will be enhanced by applying those constant Triassic layer thickness values to a 3D seismic reflection survey done in 2018 in Northern Alsace over $200 \mathrm{~km}^{2}$ (Richard et al. 2019). It is very important for preparing complex well trajectories of future deviated wells targeting nearly vertical faults to document the 3D geometrical model with accurate thickness estimation of those layers. On the other hand, when such layers show a higher thickness than expected for the Triassic sandstone layers, it could be interpreted as the trace of a normal fault which thickened this sedimentary layer. Such a result was observed in the Soultz GPK-1 well in the Buntsandstein sandstone by Aichholzer et al. (2016).

\section{Conclusion}

Based on the 484-m-continuous cores of excellent quality, this analysis was conducted to give solid petrographic and stratigraphic data for future chronostratigraphic interpretations of wells. This paper gives for the first time a realistic description of each formations' lithofacies and corresponding gamma-ray responses from the middle Muschelkalk to the Buntsandstein formations. In the EPS-1 well (Soultz-sous-Forêts), the basement was reached at $1417 \mathrm{~m}$ depth. After studying the cores between 933 and $1417 \mathrm{~m}$, it became possible to propose a precise stratigraphic frame and to analyze the lithofacies from the middle Muschelkalk up to the basement, associated with the GR signals. A synthesis of all core descriptions with the most representative photos of each formation is given. Afterward, with the spatial correlation of the core observations with their descriptions, it is possible to explain the variations in the gamma-ray signals acquired in the EPS-1 well.

The GR signal corresponds to a physical response from the lithologic facies, and each variation in the formation composition induces a specific signal. Many facies observed in the cores are compared to equivalent ones in the field. The most evident transition is the strong shift of the GR signal between the sedimentary cover (base of the Permian) and the basement observed at $1417 \mathrm{~m}$ deep. The Variscan basement is primarily composed of radioactive minerals, and its GR signal is, therefore, very high.

In the Muschelkalk, from top to base we can observe that the signal can be divided into two main parts. The first part corresponds to the Marnes Bariolées (middle Muschelkalk) showing a great cyclic signal linked to the alternation of dolomite/marls. Further, downward, the main shifts to the left are related to the high percentage of anhydrite that is characteristic of the lower part of the middle Muschelkalk. In the second part of lower Muschelkalk, the GR signal shows low values due to the massive dolomitic complex of the Couches à Orbicularis, Schaumkalk and Wellenkalk, and then increases progressively from the top to the base. 
On a first order, the transition between the Muschelkalk and the Buntsandstein is obvious, with a consistent increase in the GR throughout the lower Muschelkalk linked to the clay increase, until its maximum at the Grès Argileux (Buntsandstein) and Grès à Meules (Buntsandstein) transition. From there, the signal progressively decreases again until it reaches the Poudingue de Sainte-Odile, in which the signal is linked to the decrease in clay observed in each formation from the Grès à Voltzia through the Couches Intermédiaires progressively less clayey and sandier. The Poudingue de Sainte-Odile has an important leftwards GR signal which presents two broad curve-shaped signals clearly distinct from the formations above and below. The homogeneous underlying Grès Vosgien and the clayey Permian formations are also evident on the GR log, with a very long stable signal linked to the former, and a shift to a more radioactive signal linked to the latter. In the linear signal of the Grès Vosgien, there are two interesting signals: the amplitude and frequency variation observed in the Couches de Karstal (even if linear on a first order), which can be attributed to the two types of facies of the formation (playa like facies composed of more clayey deposits, in fact, millimetric sand-clay alternations, and aeolian dunes characterized by more sandy arenites); and three peaks with a strong push to the right at the top of the Couches de Trifels, which correspond to the three thick clay banks occurring at the top of the formation (observed on the cores and also present in the GRT-1 and GRT-2 wells at Rittershoffen).

The Permian formations, being more clay-rich, therefore have a higher gamma-ray signal than the Grès Vosgien. Thus, a jump in the GR value at the transition between the Grès d'Annweiler and the first Permian formation is observed. In the case of the Grès Anté-Annweiler, which has a lower content of clay than the first Permian formation (Grès d'Annweiler), a decrease in the GR signal is observed in the log. Otherwise, many facies are also more coarse grained. However, since it has a higher clay content than the Grès Vosgien, the signal does not decrease below the Grès Vosgien gamma-ray value.

With few outcrops in the region for the middle and lower Muschelkalk, having this complete description with high-quality photo boards of each formation brings an important base not only for all the future geothermal wells drilled in the region, but also for the reinterpretation of old well logs.

\section{Acknowledgements}

We would like to thank Charlotte Wolff for her participation and involvement in the initial project with the establishment of the first geological log. We would also like to kindly thank the two anonymous reviewers and the editor for their contributions and manuscript improvement.

\section{Authors' contributions}

AC and PD analyzed all the sedimentary data available (EPS-1 cores, gamma-ray, and field works) and positioned the sedimentary limits of the formations encountered by the EPS-1 well. AG worked on the application of lithostratigraphic tools ongoing geothermal wells in Alsace, the granitic part of the EPS-1 cores and added the observation of the GRT-1 well logs. AC prepared the manuscript with contributions from all co-authors. All authors read and approved the final manuscript.

\section{Funding}

The present work has been conducted under the framework of the LABEX ANR-11-LABX-0050-G-EAU-THERMIEPROFONDE and benefits from a state funding managed by the French National Research Agency (ANR) as part of the "Investments for the Future" program. The authors are grateful to GEIE Exploitation Minière de la Chaleur for accessing the cores and geophysical data available at Soultz-sous-Forêts, ADEME and ÉS are also acknowledged in the framework of EGS Alsace project.

Availability of data and materials

The cores are stored at the Pechelbronn-Merkwiller core shelter. Geophysical logs such as gamma-ray may be obtained from the digitized georeferenced data from the BRGM, the French Geological Survey. 


\begin{abstract}
Author details
${ }^{1}$ Ecole et Observatoire des Sciences de la Terre (EOST), Institut de Physique du Globe de Strasbourg (IPGS), CNRS/Unistra UMR 7516, Université de Strasbourg (Unistra), 1 rue Blessig, 67084 Strasbourg Cedex, France. ${ }^{2}$ ES-Géothermie, Le Belem, 5 rue de Lisbonne, 67300 Schiltigheim, France.
\end{abstract}

Received: 17 May 2019 Accepted: 24 October 2019

Published online: 16 November 2019

\title{
References
}

Adloff MC, Doubinger J, Geisler D. Étude palynologique et sédimentologique dans le Muschelkalk moyen de Lorraine. Mém Sci Terre. 1982;25:91-104.

Aichholzer C. Le log complet de la stratigraphie de la zone rhénane ainsi que les modalités stratigraphiques, sédimentaires et structurales de la transition «socle-couverture». Application à la géothermie profonde. Thèse d'état de I'Université de Strasbourg, Strasbourg; 2019; p. 532.

Aichholzer C, Duringer P, Orciani S, Genter A. New stratigraphic interpretation of the Soultz-sous-Forêts 30-year-old geothermal wells calibrated on the recent one from Rittershoffen (Upper Rhine Graben, France). Geotherm Energy. 2016;4(1):13. https://doi.org/10.1186/s40517-016-0055-7.

Aigner T. Schill-Tempestite im Oberen Muschelkalk (Trias, SW-Deutschland). Neues Jahrb Für Geol Paläontol Abh. 1979;157(3):326-43.

Aigner T. Storm depositional systems: dynamic stratigraphy in modern and ancient shallow-marine sequences. Berlin: Springer-Verlag; 1985. p. 3

Alexandrov P, Royer J-J, Deloule E. 331 I 9 Ma emplacement age of the Soultz monzogranite (Rhine Graben basement) by U/Pb ion-probe zircon dating of samples from $5 \mathrm{~km}$ depth. Comptes Rendus Académie Sci Ser IIA Earth Planet Sci. 2001;332(12):747-54. https://doi.org/10.1016/S1251-8050(01)01594-4.

Bauer JF, Meier S, Philipp SL. Architecture, fracture system, mechanical properties and permeability structure of a fault zone in Lower Triassic sandstone, Upper Rhine Graben. Tectonophysics. 2015;647-648:132-45. https://doi. org/10.1016/j.tecto.2015.02.014.

Baujard C, Genter A, Dalmais E, Maurer V, Hehn R, Rosillette R, Vidal J, Schmittbuhl J. Hydrothermal characterization of wells GRT-1 and GRT-2 in Rittershoffen, France: implications on the understanding of natural flow systems in the rhine graben. Geothermics. 2017;65:255-68. https://doi.org/10.1016/j.geothermics.2016.11.001.

Berger JP, Reichenbacher B, Becker D, Grimm M, Grimm K, Picot L, Storni A, Pirkenseer C, Derer C, Schaefer A. Paleogeography of the Upper Rhine Graben (URG) and the Swiss Molasse Basin (SMB) from Eocene to Pliocene. Int J Earth Sci. 2005a;94(4):697-710. https://doi.org/10.1007/s00531-005-0475-2.

Berger JP, Reichenbacher B, Becker D, Grimm M, Grimm K, Picot L, Storni A, Pirkenseer C, Schaefer A. Eocene-Pliocene time scale and stratigraphy of the Upper Rhine Graben (URG) and the Swiss Molasse Basin (SMB). Int J Earth Sci. 2005b;94(4):711-31. https://doi.org/10.1007/s00531-005-0479-y.

Bergerat F. Stress fields in the European platform at the time of Africa-Eurasia collision. Tectonics. 1987;6(2):99-132. https ://doi.org/10.1029/TC006i002p00099.

Blanc-Valleron MM. Les Formations paléogènes évaporitiques du bassin potassique de Mulhouse et des bassins plus septentrionaux d'Alsace. Published thesis: Thèse de doctorat de I'Université de Strasbourg, Strasbourg; 1990.

Bourgeois O, Ford M, Diraison M, Carlier Le, de Veslud C, Gerbault M, Pik R, Ruby N, Bonnet S. Separation of rifting and lithospheric folding signatures in the NW-Alpine foreland. Int J Earth Sci. 2007;96(6):1003-31. https://doi.org/10.1007/ s00531-007-0202-2.

Bourquin S, Durand M. International field workshop on » The Triassic of Eastern France» (October 2-7, 2006). Pan-Eur. Correl. Épicontinental Triassic Géosciences Rennes UMR 6118 CNRS 80; 2007.

Bourquin S, Peron S, Durand M. Lower Triassic sequence stratigraphy of the western part of the Germanic Basin (west of Black Forest): fluvial system evolution through time and space. Sediment Geol. 2006;186(3):187-211. https://doi. org/10.1016/j.sedgeo.2005.11.018.

Clauer N, Liewig N, Ledesert B, Zwingmann $\mathrm{H}$. Thermal history of Triassic sandstones from the Vosges Mountains-Rhine Graben rifting area, NE France, based on K-Ar illite dating. Clay Miner. 2016;43(3):363-79. https://doi.org/10.1180/ claymin.2008.043.3.03.

Cocherie A, Guerrot C, Fanning MC, Genter A. Datation U-Pb des deux faciès du granite de Soultz (Fossé rhénan, France). Comptes Rendus Geosci. 2004;336(9):775-87.

Dachroth W. Fluvial sedimentary styles and associated depositional environments in the Buntsandstein west of river Rhine in Saar area and Pfalz (FR Germany) and Vosges (France). In: Mader D, editor. Aspects of fluvial sedimentation in the Lower Triassic Buntsandstein of Europe. 4th ed. Berlin: Springer-Verlag; 1985. p. 197-248.

Degouy M, Villeneuve B, Weber R. Logistical support and development of the Soultz hot dry rock site: -seismic observation wells - well EPS-1. 1990-1991 Soultz-sous-Forêts (France). Final Report 92 CFG 09. RR-41179-FR. BRGM Service géologique national; 1992.

Dezayes C, Lerouge C. Reconstructing Paleofluid circulation at the Hercynian basement/Mesozoic sedimentary cover interface in the Upper Rhine Graben. Geofluids Geofluids. 2019;30:1-30. https://doi.org/10.1155/2019/4849860.

Doebl F, Olbrecht W. An isobath map of the Tertiary base in the Rhinegraben. In: Illies JH, Fuchs K. Eds. Approaches Taphrogenesis Schweiz. Verlagsbuchhandlung Stuttg. 1974; p. 71-72.

Durand M. Paléocourants et reconstitution paléogéographique. L'exemple du Buntsandstein des Vosges méridionales (Trias inférieur et moyen continental). Published thesis: Thèse d'état de I'Université de Nancy, Nancy; 1978.

Durand M. Le Trias de Lorraine et Alsace septentrionales. Bull Inf Géologues Bassin Paris. 2010;47(1):13-21. 
Durand M. Der Buntsandstein in Nordost-Frankreich. In: Lepper H, Röhling G. Ed. Deutsche Stratigraphische Kommission (Hrsg., Koordination und Redaktion: J für die Subkommission Perm-Trias: Stratigraphie von Deutschland XI. Buntsandstein). Schriftenreihe der Deutschen Gesellschaft für Geowissenschaften. 2013; 69. P. 635-646.

Duringer P. Sédimentologie et paléoécologie du Muschelkalk supérieur et de la Lettenkohle (Trias germanique) de l'est de la France : diachronie des faciès et reconstitutions des paléoenvironnements. Published thesis: Université de Strasbourg, Strasbourg; 1982; p. 96.

Duringer P. Tempêtes et tsunamis; des dépôts de vagues de haute énergie intermittente dans le Muschelkalk supérieur (Trias germanique) de l'Est de la France. Bull Société Géologique Fr. 1984;7(6):1177-85.

Duringer P. Stratégie adaptive de la croissance de Placunopsis ostracina SCHLOTHEIM, épizoaire du Muschelkalk supérieur (Trias germanique de l'Est de la France). N Jb Geol Paläont Mh. 1985;1:1-22.

Duringer P. Les conglomérats des bordures du rift Cénozoïque Rhénan. Dynamique sédimentaire et contrôle climatique. Published thesis: Thèse d'état de I'Université de Strasbourg, Strasbourg; 1988. P. 278.

Duringer P, Vecsei A. Middle Triassic shallow-water limestones from the Upper Muschelkalk of eastern France: the origin and depositional environment of some early Mesozoic fine-grained limestones. Sediment Geol. 1998;121(12):57-70. https://doi.org/10.1016/50037-0738(98)00069-4.

Duringer P, Aichholzer C, Orciani S, Genter A. The complete stratigraphic log of geothermal wells at Rittershoffen (Upper Rhine Graben, eastern France): new insights into the regional stratigraphy and a key for future geothermal wells. Bull Soc Géol Fr. 2019. https://doi.org/10.1051/bsgf/2019012.

Edel JB, Schulmann K, Rotstein Y. The Variscan tectonic inheritance of the Upper Rhine Graben: evidence of reactivations in the Lias, Late Eocene-Oligocene up to the recent. Int J Earth Sci. 2007;96(2):305-25. https://doi. org/10.1007/s00531-006-0092-8.

Gall JC. Faunes et paysages du Grès à Voltzia du nord des Vosges. Essai paléoécologique sur le Buntsandstein supérieur. Mém Serv Carte Géologique Alsace Lorraine. 1971;34(1):1-318.

Gall JC. Permanence du régime de chenaux et de flaques dans les Vosges du Nord pendant toute la durée du Buntsandstein. Sci Géologiques, Bull et Mém. 1972;25(4):307-22.

Gall JC. Fluvial depositional environment evolving into deltaic setting with marine influences in the Buntsandstein of Northern Vosges (France). In: Mader D, editor. Aspect of fluvial sedimentation in the lower triassic Buntsandstein of Europe. Berlin, Heidelberg: Springer Verlag; 1985. p. 449-77.

Geisler D. Une coupe détaillée du Muschelkalk moyen à Sarrebourg (Moselle). 103e Congrès Nat Soc Sav Sci. 1978:4:335-41.

Geisler-Cussey D. Approches sédimentologiques et géochimiques des mécanismes générateurs de formations évaporitiques actuelles et fossiles : marais salants de Camargue et du Levant espagnol, messinien méditerranéen et Trias lorrain. Sci Terre Nancy. 1986;48:226.

Genter A, Traineau H (1991) Geological survey of the HDR borehole EPS1, Soultz-sous-Forêts, Alsace-France. Part 1 Field Report. BRGM Orléans IMRG 32433.

Genter A, Traineau H. Borehole EPS-1, Alsace, France: preliminary geological results from granite core analyses for Hot Dry Rock research. Sci Drill. 1992;3(5):205-14. https://doi.org/10.1016/0148-9062(93)92984-X.

Genter A, Traineau H. Analysis of macroscopic fractures in granite in the HDR geothermal well EPS-1, Soultz-sousForêts, France. J Volcanol Geotherm Res. 1996;72(1-2):121-42.

Gérard A, Kappelmeyer O. The Soultz-sous-Forets project. Geothermics. 1987;16(4):393-9. https://doi. org/10.1016/0375-6505(87)90018-6.

Haas JO, Hoffmann CR. Temperature gradient in Pechelbronn Oil-Bearing Region, Lower Alsace: its determination and relation to oil reserves. AAPG Bull. 1929;13(10):1257-73.

Haguenauer B. Étude séquentielle du Muschelkalk supérieur Lorrain. Mém Bur Rech Géol Min. 1963;15:148-53.

Hinsken S, Schmalholz SM, Ziegler PA, Wetzel A. Thermo-Tectono-Stratigraphic forward modelling of the Upper Rhine Graben in reference to geometric balancing: Brittle crustal extension on a highly viscous mantle. Tectonophysics. 2011;509(21):1-13. https://doi.org/10.1016/j.tecto.20.

Hooijkaas GR, Genter A, Dezayes C. Deep-seated geology of the granite intrusions at the Soultz EGS site based on data from $5 \mathrm{~km}$-deep boreholes. Geothermics. 2006;35(5-6):484-506.

Illies JH. Development and tectonic pattern of the Rhinegraben. In: Rothé JP, Sauer K, editors. The Rhinegraben Progress Report. Abh Geol Landesamt Baden-Würtemberg. 6th ed. 1967; p. 7-9.

Kappelmeyer O, Gérard A, Schloemer R, Ferrandes F, Rummel F, Benderriter Y. European HDR Project at Soultz-sousForêts: General Presentation, in: Geothermal Energy in Europe - The Soultz Hot Dry Rock Project. Montreux: CRC Press; 1992. p. xvii-liii.

Köhler H. Geochronology on the granite core material from GPK1. Soultz-sous-Forêts: Ruhr-Universität Bochum Report; 1989. p. 70844.

Kozur H. Biostratigraphie der germanischen Mitteltrias, Teil I und II. - Freiberger Forschungsh. C 280(I and II): 56 p. and 71 p. Deutscher Verlag f. Grundstoffindustrie, VEB. 1974.

Leppla A. Über der Buntsandstein im Haardtgebirge (Nordvogesen). Geognost Jh, 1:39-54. Verlag nicht ermittelbar. 1888.

Mader D. Depositional mechanisms and facies models of intertonguing aeolian environment and fluvial milieu in the Middle Buntsandstein of the Mid-European Triassic Basin. In: Mader D, editor. Aspect of fluvial sedimentation in the lower triassic Buntsandstein of Europe. 4th ed. Berlin: Springer Verlag; 1985. p. 127-64.

Maurer V, Perrinel N, Dalmais E, Richard A, Plévy L, Genter A. Towards a 3D velocity model deduced from 2D seismic processing and interpretation in Northern Alsace (France). European Geothermal Congress 2016, EGC2016, 19-22 September 2016, Strasbourg, France; 2016.

Ménillet F, Durand M, Genter A, Party JP. Notice de la carte géologique de France (1/50000), feuille Haguenau. Zème éd. Carte Géologique Fr. Serv. Géologique Natl. BRGM; 2015.

Ménillet F, Coulombeau C, Geissert F, Konrad HJ, Schowoerer P. Notice de la carte géologique au 1: 50 000ième: Lembach. BRGM: Carte Géologique Fr. Serv. Géologique Natl; 1989. 
Müller EM. Beiträge zur Kenntnis der Stratigraphie und Paläogeographie des Oberen Buntsandsteins im SaarLothringischen Raum. Published thesis: Universität im Sarrelandes, Sarrebruck; 1954a.

Müller EM. Die Ausbildung und Mächtigkeit der Zwischenschichten im Saar-Lothringischen Raum. Annales Universiiatis Saraviensis III. 1954a;1-2:68-74.

Müller EM. Beiträge zur Kenntnis der Stratigraphie und Paläogeographie des oberen Buntsandstein im Saar-Lothringischen Raum. Annales Universiiatis Saraviensis III. 1954b;3:176-201.

Schuler M. Environnements et paléoclimats paléogènes. Palynologie et biostratigraphie de l'Eocène et de l'Oligocène inférieur dans les fossés rhénan, rhodanien et de Hesse. Published thesis: Thèse de doctorat de l'Université de Strasbourg, Strasbourg. 1988; p. 503.

Perriaux J. Contribution à la géologie des Vosges gréseuses. Mém Serv Carte Géologique Alsace Lorraine. 1961;18:1-236.

Perrin J, Baudu R. Recalage en profondeur des carottes du forage EPS-1 de Soultz-sous-Forêts (Bas-Rhin) (projet Géothermie profonde), par corrélation des enregistrements de gamma-densimétrie sur carottes avec la diagraphie gammagamma en puits. Rapport du BRGM : R 35034 GPH SGN 92. 1992; p. 27.

Richard A, Maurer V, Edel JB, Genter A, Baujard C, Dalmais E. Towards targeting geothermal reservoir: exploration program for a new EGS project in urban context in Alsace. European Geothermal Congress 2016, EGC2016, 19-22 September 2016, Strasbourg, France; 2016.

Richard A, Gillot E, Maurer V, Cuenot N, Klee J. Northern Alsace (France): the largest geothermal exploration area by 3D seismic reflection, European Geothermal Congress, EGC 2019, 11-14 June 2019. The Netherlands: The Hague; 2019.

Rotstein Y, Schaming M, Rousse S. Tertiary tectonics of the Dannemarie Basin, upper Rhine graben, and regional implications. Int J Earth Sci. 2005;94(4):669-79. https://doi.org/10.1007/s00531-005-0473-4.

Rousse S. Architecture et dynamique des séries marines et continentales de l'Oligocène Moyen et Supérieur du Sud du Fossé Rhénan: évolution des milieux de dépôt en contexte de rift en marge de l'avant-pays alpin. Published thesis: Thèse de doctorat de I'Université de Strasbourg; 2006; p. 474.

Schumacher E. Zur Kenntniss des unteren Muschelkalk im nordlischen Deutsch-Lothringen. Mitt Geol Anst Els-Lothr. 1890;2:111-82.

Schumacher E. Erläuterungen zu Blatt Volmunster. Geol Spez Kt Von Els-Lothr. 1891;28:64.

Schumacher ME. Upper Rhine Graben: role of preexisting structures during rift evolution: Upper Rhine Graben evolution. Tectonics. 2002;21(1):616-7. https://doi.org/10.1029/2001TC900022.

Schwarz HU. Zur Sedimentologie und Fazies des unteren Muschelkalkes in Südwestdeutschland und angrenzenden Gebieten. Published thesis: Universität Tubingen. 1970; p. 213.

Sissingh W. Comparative tertiary stratigraphy of the Rhine Graben, Bresse Graben and Molasse Basin: correlation of Alpine foreland events. Tectonophysics. 1998;300(1-4):249-84. https://doi.org/10.1016/S0040-1951(98)00243-1.

Sissingh W. Tertiary paleogeographic and tectonostratigraphic evolution of the Rhenish triple junction. Palaeogeogr Palaeoclimatol Palaeoecol. 2003;196(1-2):229-63. https://doi.org/10.1016/S0031-0182(03)00320-1.

Sittler C (1965) Le paléogène des fossés rhénan et rhodanien. Etudes sédimentologiques et paléoclimatiques, Mémoire du Service de la carte géologique d'Alsace et de Lorraine, vol. 24. 1965.

Sittler C. Le fossé Rhénan en Alsace, aspect structural et histoire géologique. Rev Geogr Phys Geol Dyn. 1969a;11(5):465-94.

Sittler C. The sedimentary trough of the Rhine graben. Tectonophysics. 1969b;8(4-6):543-60. https://doi. org/10.1016/0040-1951(69)90053-5.

Sittler C. Illustration de I'histoire géologique du Fossé Rhénan et de I'Alsace. Neues Jahrb Für GeolPaläontolAbh. 1992;186(3):255-82

Stussi JM, Cheilletz A, Royer JJ, Chèvremont P, Féraud G. The hidden monzogranite of Soultz-sous-Forêts (Rhine Graben, France). Miner Petrol Genes Géologie de la France. 2002;1:45-64.

Théobald N. Stratigraphie du Trias moyen dans le SW de I'Allemagne et le NE de la France. Publisched thesis: Universität des Saarlandes. 1952; p. 63.

Thürach H. Bericht über die Excursionen am 29 und 30 Marz und 1 April. Ber Versamml Oberrh. Geol Ver. 1894;27:27-71.

Trusheim F. Über Diskordanzen im Mittleren Buntsandstein Nortddeutschland zwischen Ems und Weser. Erdoel-Z. 1961;77(9):361-7.

Valley B. The relation between natural fracturing and stress heterogeneities in deep-seated crystalline rocks at Soultzsous-Forêts (France), Published thesis: Université ETH-Zürich, Switzerland. 2007; p. 260.

Vecsei A, Duringer P. Sequence stratigraphy of Middle Triassic carbonates and terrigenous deposits (Muschelkalk and Lower Keuper) in the SW Germanic Basin: maximum flooding versus maximum depth in intracratonic basins. Sediment Geol. 2003;160(1-3):81-105.

Vernoux JF, Genter A, Razin P, Vinchon C. Geological and petrophysical parameters of a deep fractured sandstone formation as applied to geothermal exploitation. EPS-1 borehole, Soultz-sous-Forêts, France. Rapp. BRGM RR-38622-FR 38622, 70. 1995.

Villemin T, Bergerat F. L'évolution structurale du fossé rhénan au cours du Cénozoïque: un bilan de la déformation et des effets thermiques de l'extension. Bull Soc Géol Fr. 1987;3(2):245-55.

Ziegler PA. European Cenozoic rift system. Tectonophysics, Geodynamics of rifting. 1992;208(1-3):91-111. https://doi. org/10.1016/0040-1951(92)90338-7.

Ziegler PA, Dèzes P. Evolution of the lithosphere in the area of the Rhine Rift System. Int J Earth Sci. 2005;94(4):594-614. https://doi.org/10.1007/s00531-005-0474-3.

\section{Publisher's Note}

Springer Nature remains neutral with regard to jurisdictional claims in published maps and institutional affiliations. 